\title{
Iceland: Selected Issues Paper
}

This paper was prepared based on the information available at the time it was completed on September 13, 2010. The views expressed in this document are those of the staff team and do not necessarily reflect the views of the government of Iceland or the Executive Board of the IMF.

The policy of publication of staff reports and other documents by the IMF allows for the deletion of market-sensitive information.

Copies of this report are available to the public from

International Monetary Fund • Publication Services

700 19th Street, N.W. • Washington, D.C. 20431

Telephone: (202) 623-7430 • Telefax: (202) 623-7201

E-mail: publications@imf.org • Internet: http://www.imf.org

\section{International Monetary Fund Washington, D.C.}




\section{INTERNATIONAL MONETARY FUND}

\section{ICELAND}

\section{Selected Issues}

Prepared by Mark Flanagan, Wojciech Maliszewski, Iva Petrova, and Mali Chivakul Approved by the European Department

September 13, 2010

Contents

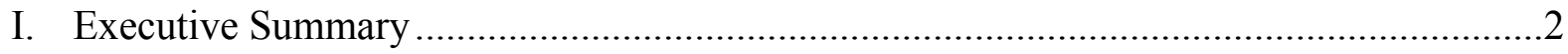

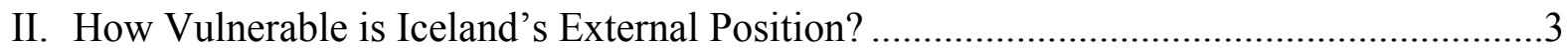

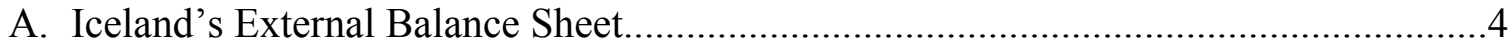

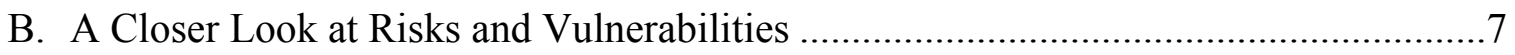

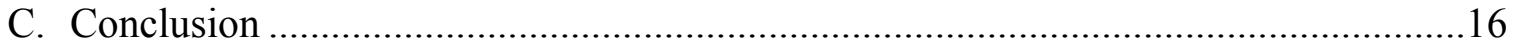

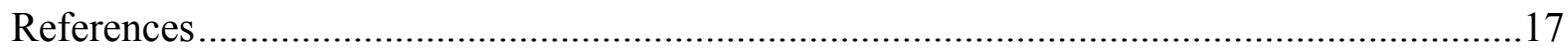

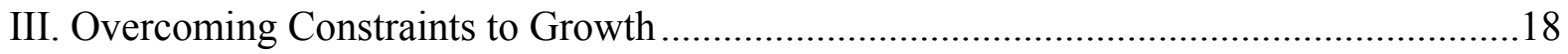

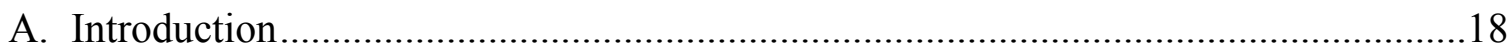

B. The Structure of the Icelandic Economy ................................................................18

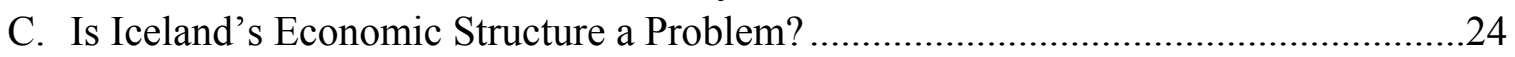

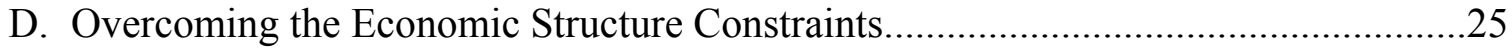

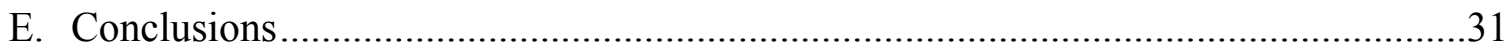

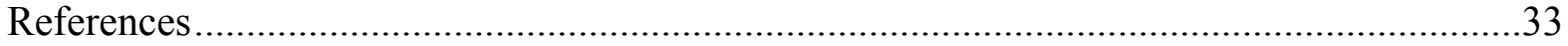

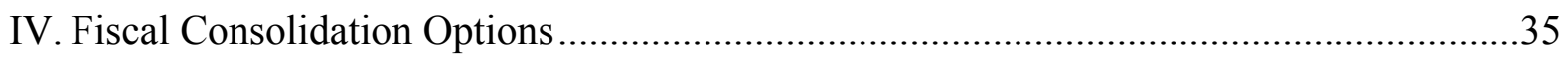

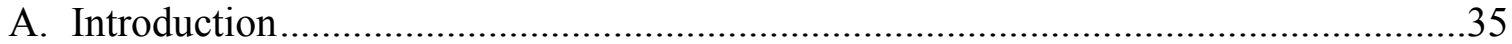
B. Background: Fiscal Consolidation Objectives and Options .........................................36

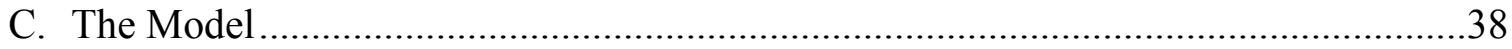

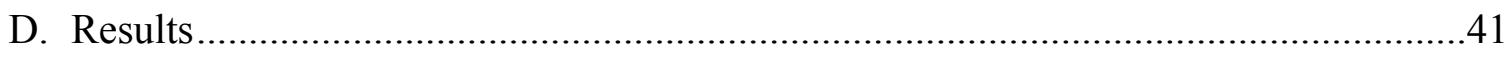

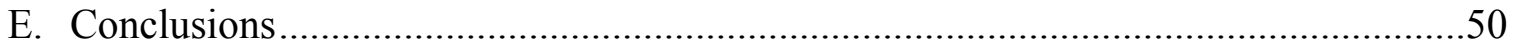

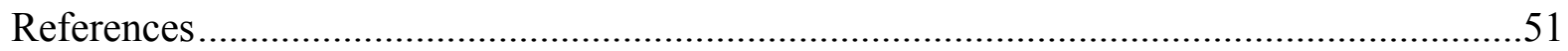




\section{EXECUTIVE SUMMARY}

1. Iceland faces a significant debt sustainability challenge. The 2008 financial crisis saw Iceland's public debt soar from under 30 to over 100 percent of GDP, and while underlying external debt came down sharply (as heavily indebted banks collapsed into bankruptcy), it remains elevated at close to 300 percent of GDP. Standard debt dynamics identities link the evolution of debt to the level of interest rates and the exchange rate and the pace of economic growth. Given these macro parameters, the primary fiscal position drives public debt dynamics, while the primary current account surplus drives external debt dynamics. A key complication is that the macro parameters depend on the pace of policy adjustment. The Selected Issues Papers in this volume examine this nexus in more depth.

2. The first chapter looks more closely at external debt sustainability. A closer look at sectoral balance sheets helps illuminate the nature of interest and exchange rate risks. For the corporate sector much of the external debt is FDI related, and many corporations have natural hedges through assets or fx income, suggesting that even long-lived shocks to the exchange rate may not greatly damage external debt sustainability. For the sovereign sector, the key issue is interest rate risk. Contingent claims analysis suggests that the pace of fiscal consolidation is of paramount importance in managing this, and the manner in which contingent liabilities play out is also important (in particular the nature of a future Icesave settlement). Spillover analysis shows Iceland relatively unaffected by recent events in sovereign debt markets, demonstrating the importance of the present policy framework.

3. The second chapter addresses Iceland's growth challenge. Iceland's production and export structure is comparatively narrow with weak links to the densest part of the global production space. Cross-country evidence suggests that such a structure could well constrain growth potential. There also appear to be constraints to scaling up Iceland's existing production. Still, Iceland has room to support export diversification into strategic goods related to its comparative advantage, for instance by maintaining a competitive exchange rate, and a liberal trade regime, and by removing barriers to investment in "backbone" infrastructure, particularly in the energy sector. The latter efforts would also support a scaling up of existing production, addressing downside risks to growth.

\section{The third chapter looks at fiscal adjustment and its macroeconomic impacts.}

Model simulations, using the IMF's Global Integrated Monetary and Fiscal model calibrated to Iceland, suggest that an expenditure-oriented fiscal adjustment would give a boost to domestic demand and growth. They indicate that an emphasis on better targeting of transfers would also help contain impacts on the trade balance. The simulations show that if the pace of debt reduction is not quick enough to prevent pressure through interest rate channels, debt reduction could stall. Finally, the simulations show that the presently-programmed pace of adjustment provides protection against the realization of new fiscal contingent liabilities and against an increase in the foreign currency risk premium. This, in turn, opens up greater room for other policies (e.g., capital control liberalization). 


\section{How Vulnerable is ICEland’s External Position?}

\section{Iceland's high external debt} level has attracted attention. At about 300 percent of GDP, Iceland's external debt appears high even by advanced country standards. Among the countries that have Fund programs, Iceland has the highest external debt. This has raised questions about whether, at some point in the future, Iceland may face a liquidity or even solvency problem.

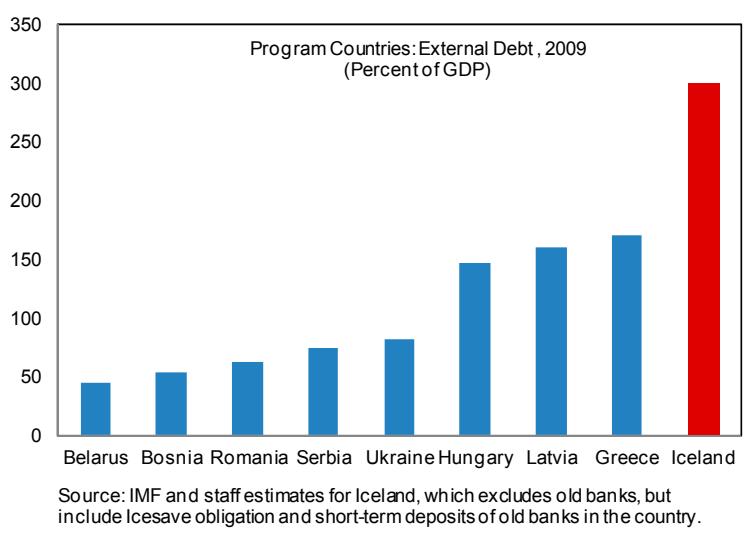

\section{The traditional approach to external debt sustainability analysis suggests that} Iceland's debt is sustainable, but signals vulnerability along several dimensions. Traditional sustainability analysis takes a country's projected medium-term debt path under the baseline macroeconomic outlook, and subjects it to a host of different shocks and scenarios. Under the program macroeconomic baseline, external debt is projected to fall slowly to around 190 percent of GDP by 2015. Stress tests suggest that this downward trajectory is robust: standard shocks would slow down but not stop debt from declining. An important shock is the exchange rate: a 30 percent permanent depreciation would drive up external debt to a much higher level. Another important shock is to the interest rate, and the analysis suggests that debt declines are robust to a shock of $150 \mathrm{bps}$.

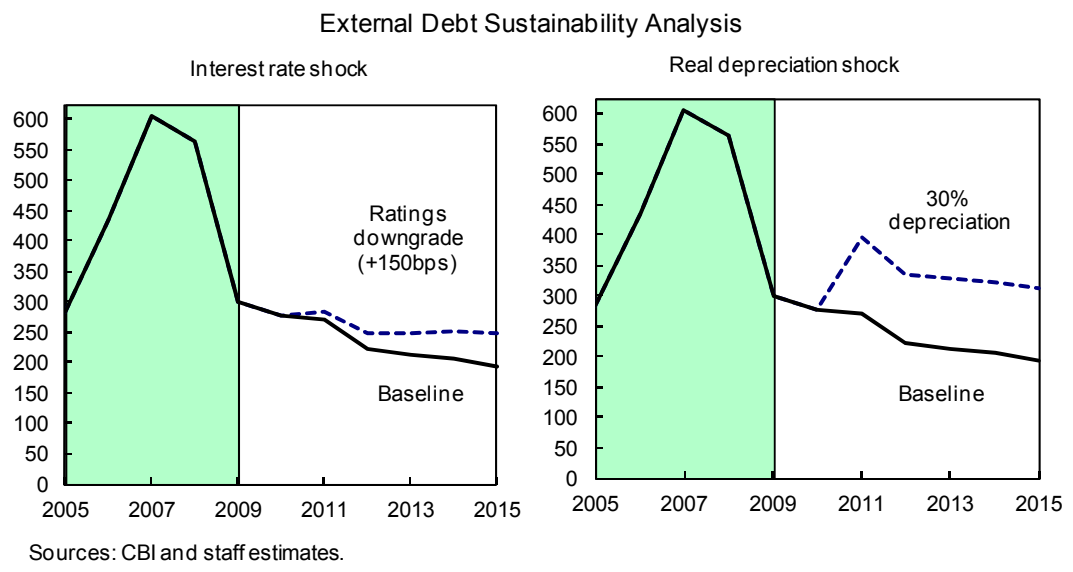

7. However, the traditional approach has some shortcomings. While in principle it can capture the factors relevant for the evolution of external debt, in practice, if offers little perspective about the role of foreign assets (and the return they generate); the full impact of

\footnotetext{
${ }^{1}$ Prepared by Mali Chivakul, with contributions from Vincenzo Guzzo and Dale Gray (MCM).
} 
the exchange rate (accounting for asset and income hedges); and the possibility of discrete adjustments of debt (e.g. due to changes in corporate capital structure). Moreover, the simple shock that is used to illuminate the key issue of interest rate risk ignores relevant information contained in market data that can be used to calibrate a likely shock.

\section{A better picture of external vulnerability can be gained from a closer look at} balance sheets. $^{2}$ The balance sheet approach focuses on the examination of stock variablesassets and liabilities - in a country's sectoral and aggregate balance sheet. Mismatches in sectors signal vulnerability, which can then be investigated in more depth by reference to maturity mismatches, currency mismatches, capital structure and asset returns. Market information can help shed light on interest rate risks.

9. This paper examines Iceland's external balance sheet and its associated risks. It documents the developments of the external balance sheet before and after the crisis in 2008 at the sectoral level, noting that risks are concentrated in the corporate and sovereign sectors. It then examines these sectoral balance sheets in greater detail, shedding light on the exchange rate and interest rate risks that Iceland's economy faces.

\section{A. Iceland's external balance sheet}

10. Iceland's external position has contracted significantly since the crisis. Gross assets and liabilities have fallen from peaks in the order of five to six times GDP in 2007 to a level of around 200-300 percent of GDP at present (excluding the old banks where the bankruptcy and winding-up now in process will ultimately match claims to recovered assets).

\section{Iceland's net foreign assets are not} out-of-line with its country peers. Large assets and liabilities are not unusual for small advanced economies that are well integrated into the global financial system. It is true that

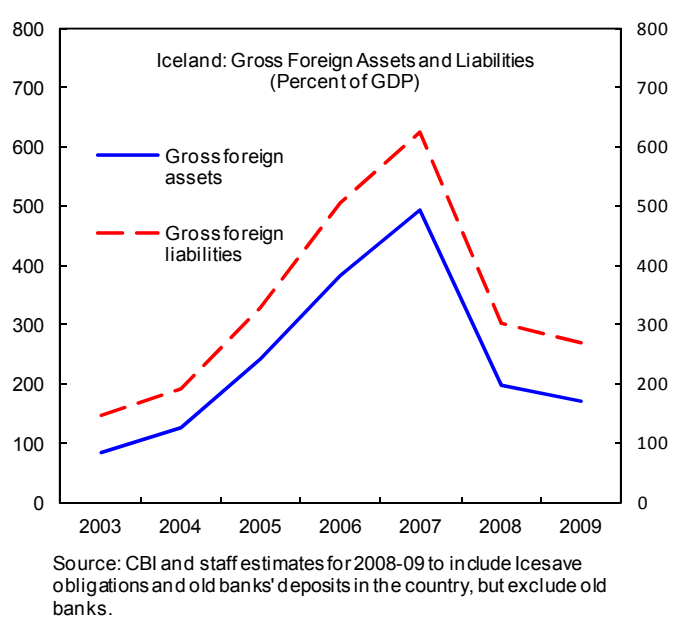
for many of Iceland's peers their outsized balance sheets reflect a large globally-integrated financial sector (gross positions from 150 to some 500 percent of GDP). However, even after taking into account the size of the financial system's NFA, Iceland is not an outlier among advanced economies.

\footnotetext{
${ }^{2}$ See Allen et al (2002) for more detail about the balance sheet approach.
} 

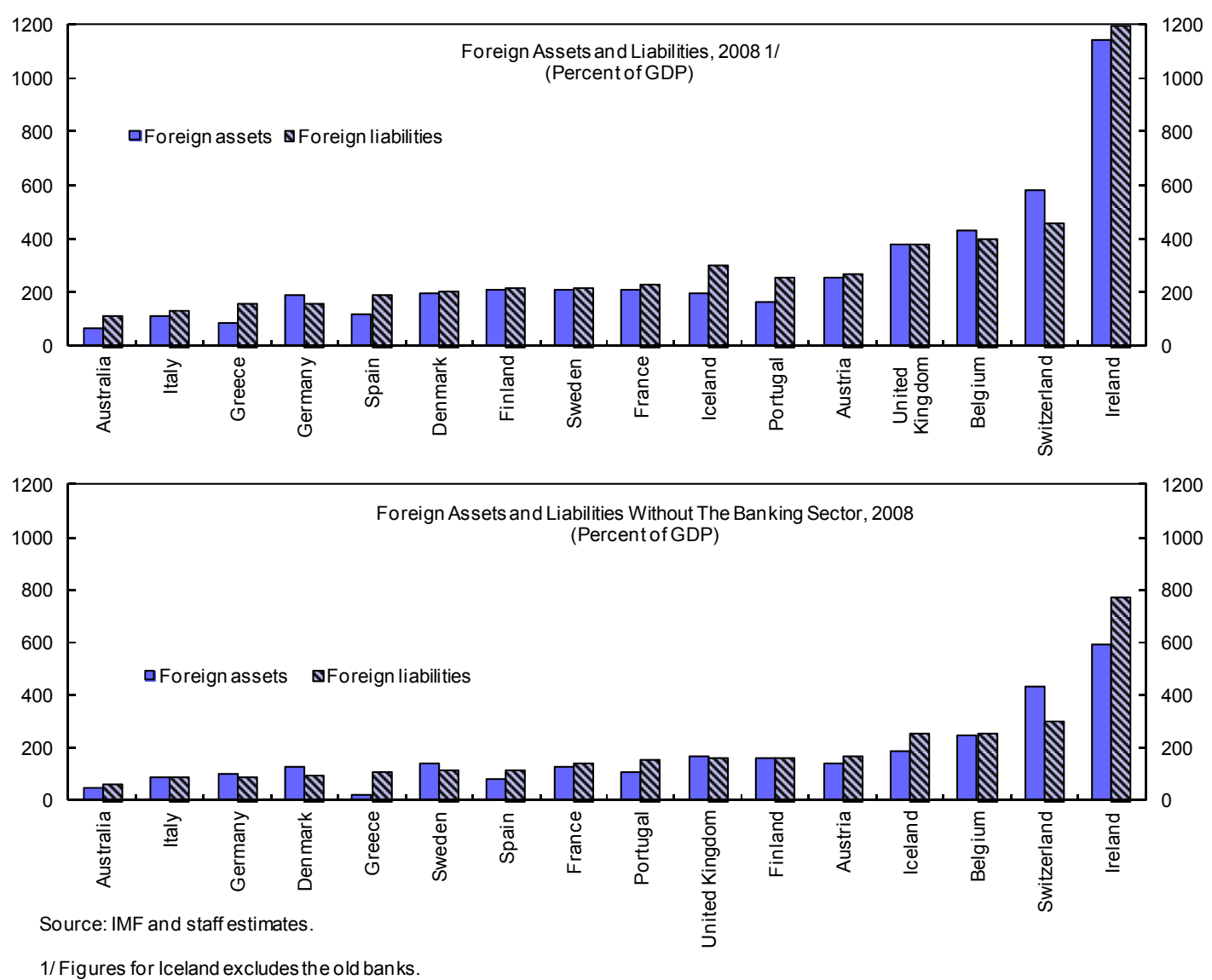

\section{Iceland's return differential on its NFA does set it apart, suggesting a}

vulnerability. Iceland's NFA has generated relatively low returns, and these deteriorated during the recent boom years. The rates of return on assets were low compared with the rates paid on liabilities. A decomposition of total return differential between Iceland's foreign assets and liabilities shows that real yield differential is consistently negative over the period from 1996 to 2007, reflecting the relatively higher interest rates in Iceland ${ }^{3}$, and the concentration of over 80 percent of Iceland's portfolio and FDI assets in advanced markets. Looking into the future, the return differential may be most pronounced for the sovereign: with a higher risk premium in the post-crisis period, the sovereign cost of borrowing is much higher than the rate it can earn on the reserves assets.

\footnotetext{
${ }^{3}$ Total return differential (between foreign assets and liabilities) is the sum of real yield differential and real rate of capital gain differential. The decomposition follows Lane and Milesi-Ferretti (2005) and Habib (2010). Other countries' figures are taken from Habib (2010).
} 
Decomposition of Total Return Differential, Average 2000-07 for Other Countries

\begin{tabular}{lcccccc}
\hline & Iceland(96-07) & Iceland (96-03) & Iceland(00-07) & Euro Area & US & Canada \\
\hline Real yield differential & -1.10 & -1.40 & -0.4 & -0.1 & 4.0 & -1.6 \\
Real rate of capital gain differential & 1.42 & 3.85 & -4.5 & -0.7 & 1.5 & -1.7 \\
Total real return differential & 0.32 & 2.46 & -4.9 & -0.8 & 5.5 & -3.3 \\
\hline
\end{tabular}

\begin{tabular}{lcccc}
\hline & Brazil & South Africa & Turkey & Poland \\
\hline Real yield differential & -3.1 & -2.9 & -0.2 & -2.1 \\
Real rate of capital gain differential & -6.0 & 0.2 & -1.4 & -4.1 \\
Total real return differential & -9.2 & -2.7 & -1.6 & -6.1 \\
\hline Source: Staff calculation and Habib (2010)
\end{tabular}

Source: Staff calculation and Habib (2010)

\section{The net external position varies between sectors, with the corporate and}

sovereign sectors most exposed. Iceland's pension funds have the largest net asset position with about 35 percent of GDP in foreign assets at end-2009 (largely unchanged from before the crisis). The sovereign sector - a combined central bank and government balance sheethas accumulated more debt associated with the crisis, mainly to boost reserves assets. The new banking system is largely in balance with little foreign assets and liabilities (although once the winding up process is complete, foreign creditors will likely ending up holding an ownership claim on the system, raising liabilities). Finally, for the corporate sector, NFA has turned around dramatically with a large reduction in the asset position.

\section{In sum, this suggests that a deeper look at corporate and sovereign sectors is} called for. Sizable exposure of the sovereign sector and its yield differential going forward make Iceland vulnerable. With much less assets than in the past, overall data suggest that corporate sector could be vulnerable as well. It is therefore important to look into these two sectors in more detail.
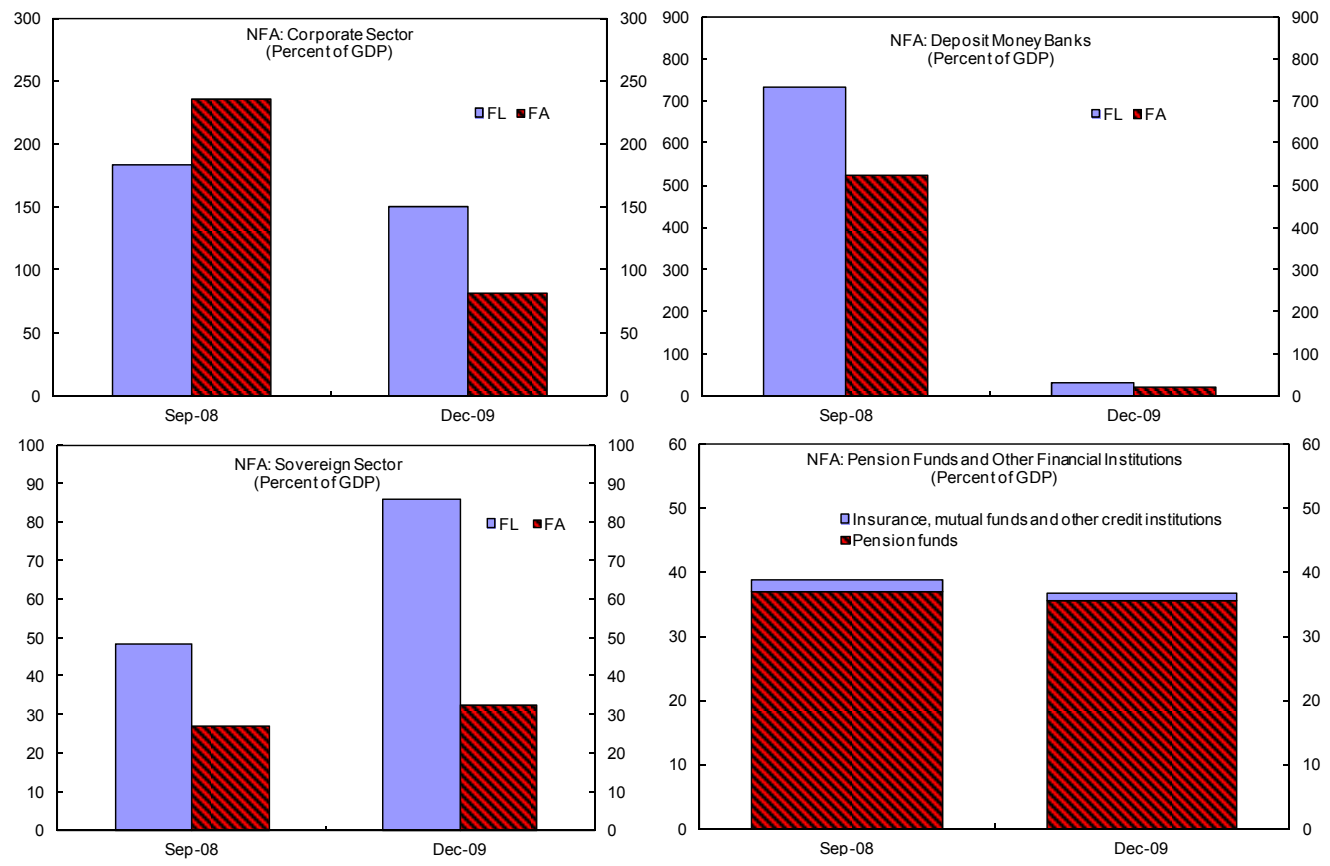

Source: $\mathrm{CB}$ and staff esimates. Foreign liabilities of DMBs include old banks' deposits in the banking system. Sovereign foreign liabilities include old banks' deposits. Both assume that the these deposits will ultimately flowout of Icelandto pay external creditors. 


\section{B. A closer look at risks and vulnerabilities}

\section{The corporate sector}

15. Is the corporate sector an important source of external vulnerability? High net external obligations alone do not necessarily create vulnerability. Corporations themselves become vulnerable due to liquidity risk and solvency risk. Still, this vulnerability may not affect the public sector, the key question being whether corporations' problems would create contingent liabilities, either directly, by the government being forced to absorb some of the debt, or indirectly, through exchange rate intervention policy.

\section{Corporations face liquidity and solvency risks, but features of the debt and of the legal framework can reduce these risks:}

- $\quad$ Liquidity risk. Currency movements can affect ability to repay obligations due. Hedging, either through income in foreign currency or foreign assets, reduces vulnerability to currency movements (and the impact on the broader economy). Intracompany debt (or FDI) reduces liquidity risk since parent companies and subsidiaries generally do not want to jeopardize each other's financial health (FDI flows are more stable than other forms of liabilities; see Brukoff and Rother (2007) for example).

- Solvency risk. A high level of foreign assets, especially combined with low asset volatility, will reduce solvency risk, since there is less chance net worth can become negative due to valuation shocks (due to currency movements for example). High flows of foreign income can also reduce solvency risk (effectively, companies are hedged). Meanwhile for companies that do face high asset volatility, a crucial question for ascertaining public sector risk whether they are purely commercial (with no government guarantee), and have access to efficient bankruptcy mechanisms.

\section{The concentration of external debt in Icelandic multinationals diminishes}

liquidity and solvency risk. 'Large' Icelandic multinationals together account for 77 percent of GDP in debt and total external liabilities. This is about half of the corporate sector's liabilities. These companies have less than 10 percent of their global operations located in Iceland, generate most of their revenues abroad and in foreign currency, and have access to foreign capital through subsidiaries or listings abroad (but since they are domiciled in Iceland, their consolidated external assets and liabilities are included in Iceland's international investment

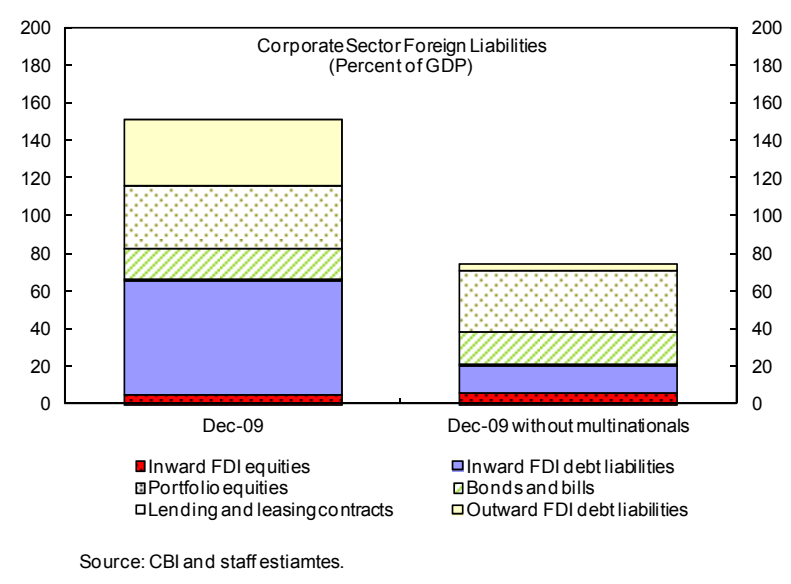


position). Market indicators suggest that these companies have lower perceived risks than the Icelandic government. Their external debt can be safely assumed to be serviced from revenue abroad, or addressed via changes in the terms and conditions of the intra-company debt (if necessary), with little pressure on Iceland's reserves, and little risk to the sovereign's balance sheet.

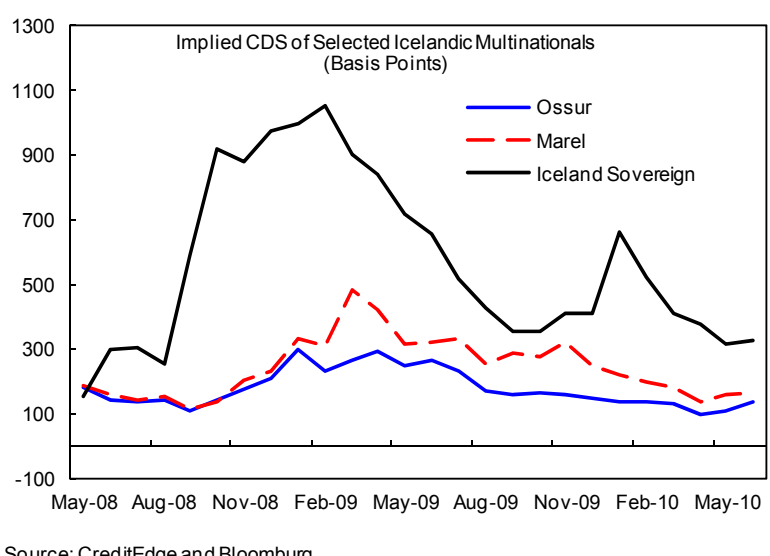

Source: CreditEdge and Bloomburg.

\section{Abstracting from Icelandic multinationals, foreign debt liabilities appear to concentrate in corporations that have natural hedges, at least in the short-run:}

- $\quad$ Inward FDI debt liabilities are concentrated among exporters, especially in the aluminum sector. Outward FDI debt liabilities are very small at about 5 percent of GDP and are wellcovered by FDI assets (16 percent of GDP), even at the company level. Aluminum accounts for 35 percent of Iceland's total exports and about 95 percent of the aluminum produced are exported.

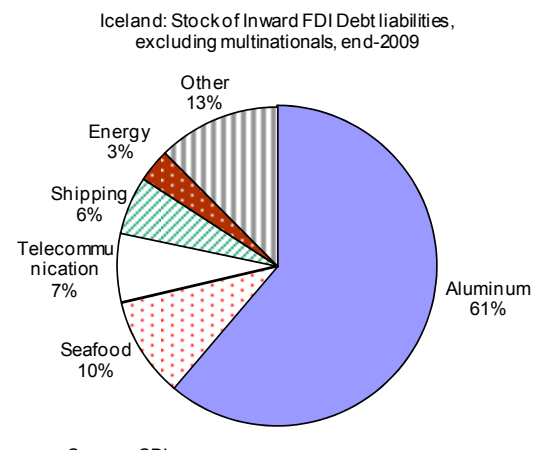

Source: $\mathrm{CB}$

- $\quad$ Non-FDI debt liabilities concentrate among public enterprises in the energy sector. These enterprises account for about half of external debt excluding multinationals ( 35 percent of GDP), and their debts are guaranteed by the government. They earn revenue in foreign exchange (generally U.S. dollars), through sales to energyintensive clients (mainly in the aluminum sector). Most of their sales contracts are long-term in nature, with the dollar price linked to the world

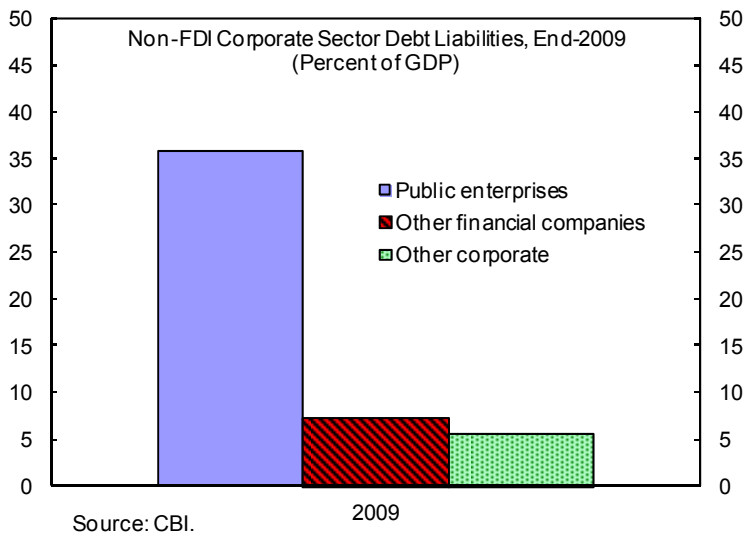
aluminum price. They are hedged generally for a period of about one year, and there is thus some residual risk to the government. This is investigated in the next section. 
- $\quad$ Although about half of the other corporate loans do not engage in export activities and have local currency revenues, they only account for about 5 percent of GDP or about 7 percent of total external debt of the corporate sector excluding the multinationals.

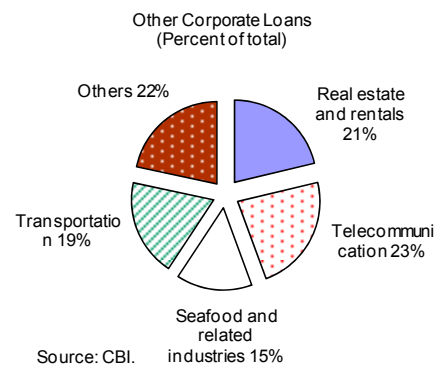

19. Finally, most companies with high solvency risks have already failed, without government bailouts. Iceland's large and connected holding companies were most vulnerable to insolvency. They only held small direct external debt, and mainly acted as investment vehicles to channel fx loans from the domestic banks into foreign assets, mostly volatile equity investments. These holding companies have gone through bankruptcy or financial restructuring, and have shed both debt and assets. Indeed, they are the principle reason for the decline in the corporate sector's NFA. However, the fact that Iceland's efficient legal system has managed to quickly process these cases, and that the government has been able to avoid any bail-out, signals that the risk of contingent liabilities in general is low for non-guaranteed corporations, and that they can resolve their debts without public sector involvement.

Iceland: Selected Large Holding Companies

\begin{tabular}{|l|l|l|}
\hline Company & Investments prior to the crisis & Status \\
\hline Baugur & $\begin{array}{l}\text { International retail companies (e.g. French } \\
\text { Connection, House of Fraser, Mosaic Fashion), } \\
\text { Iceland Supermarket chains in the UK. }\end{array}$ & $\begin{array}{l}\text { Baugur filed for } \\
\text { bankruptcy in 2009. }\end{array}$ \\
\hline Exista & $\begin{array}{l}\text { Domestic: Kaupthing Bank, VIS, Lysing, } \\
\text { Bakkavor, Skipti } \\
\text { External: Sampo Group (insurance group in } \\
\text { Finland), Storebrand (Nordic insurance company) }\end{array}$ & Moratorium. \\
\hline Stodir & $\begin{array}{l}\text { Domestic: Glitnir Bank, Landic Property,TM } \\
\text { Insurahce } \\
\text { External: Refresco (beverage group in Europe) }\end{array}$ & $\begin{array}{l}\text { Financial restructuring } \\
\text { completed in 2010. } \\
\text { Creditors are now } \\
\text { shareholders }\end{array}$ \\
\hline
\end{tabular}

Source: Companies' websites.

20. Overall, the structure of corporate external debt suggests that the depreciation shock in the standard DSA may overestimate its effects. The standard shock assumes no change in the asset and income side of the economy. However, the depreciation will also affect Iceland's foreign assets and revenues. Those with foreign currency revenues will be able to hedge themselves from the depreciation. Moreover, for Icelandic multinationals, their income generated from foreign assets will also increase with the depreciation, protecting them from the negative effect of the depreciation. This is not to say, however, that a depreciation would have no macroeconomic impact. Unhedged household and corporate fx exposures to the domestic financial system would likely result in depressed domestic demand and a drop in growth. 


\section{The sovereign risk}

21. Does the sovereign external position leave it vulnerable? A key issue for the sovereign is its risk premium: increases would imply difficult access to the capital markets both for the government, public enterprises and also for the private sector beyond the multinationals, as well as worsening external debt dynamic due to higher interest payments. This would also have an implication for public debt sustainability. To examine this risk in more depth, and better understand possible sources of shocks, two techniques can be used. First, the contingent claims approach can shed light on how various shocks to on the government might affect CDS spreads, using market information. Second, spillover analysis can be used to examine Iceland's sensitivity to external credit market shocks.

\section{Contingent claims approach}

\section{The CCA is a generalization of the option pricing theory pioneered by Black-} Scholes (1973) and Merton (1973). The basic idea is that a distress and/or default event happens when the total value of all assets decline to below the level of promised payments on the debt, referred to as the "default barrier." Default risk increases when the value of assets declines towards the default barrier or when asset volatility increases such that the value of assets becomes more uncertain and the probability of the value falling below the distress barrier becomes higher. The framework enables the derivation of credit risk indicators such as credit spreads and distance to default.

\section{CCA: Concept}

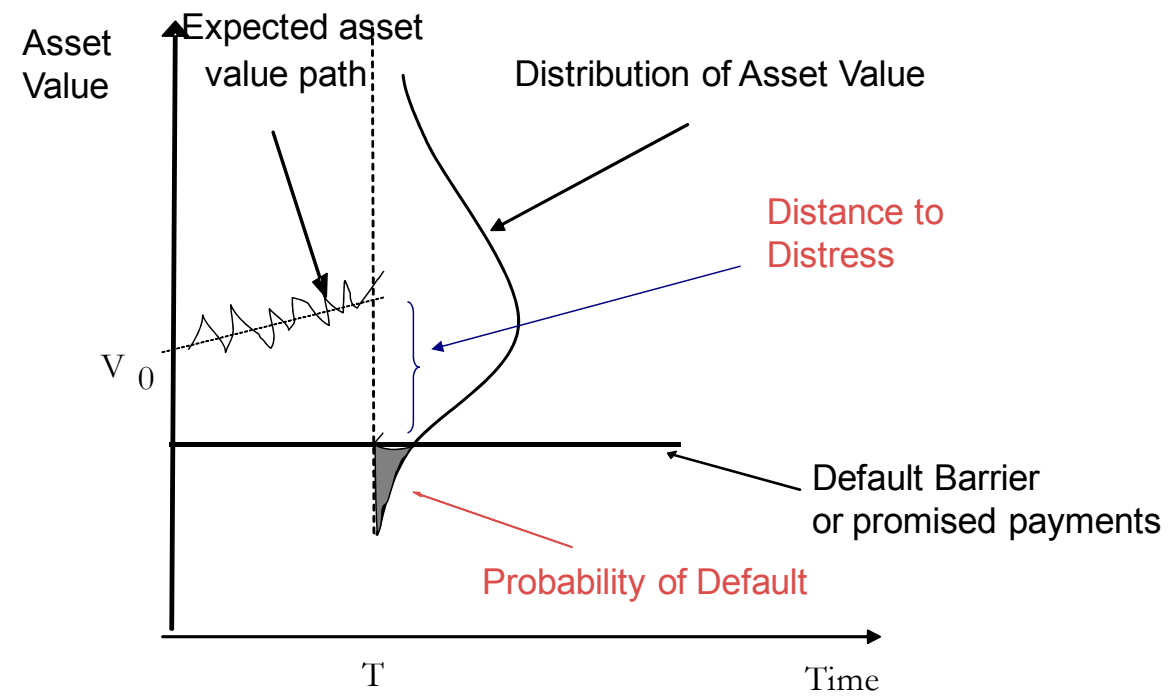


23. To apply the CCA to the sovereign sector, a sovereign balance sheet must first be constructed (see Gray, Merton and Bodie (2007) for details). Assumptions must be made about the seniority structure of the sovereign's liabilities. To derive external default risk indicators, external debt is assumed to be the more senior liability, whereas domestic debt and base money are assumed to be junior claims. The default barrier is therefore defined as the present value of the promised payments on sovereign external obligations. The sovereign is assumed to default whenever the value of its assets falls below the default barrier. The value of total sovereign assets is determined from an implied value from the observed market indicators on the liabilities ${ }^{4}$. The CCA therefore implicitly assumes that market participants' views on prices incorporate forward-looking information about the future prospects of the sovereign.

Stylized Sovereign Balance Sheet

\begin{tabular}{|l|l|}
\hline \multicolumn{1}{|c|}{ Assets } & Liabilities \\
\hline International reserves & External debt \\
\hline $\begin{array}{l}\text { Net fiscal assets (discounted value of primary } \\
\text { fiscal surpluses) }\end{array}$ & \\
\hline Value of monopoly over issue of money & Domestic debt \\
\hline Other assets less guarantees & Base money \\
\hline
\end{tabular}

Source: Gray and Malone (2008).

\section{Iceland's balance sheet is constructed as follows:}

- Sovereign external debt - the default barrier-is constructed to include several obligations. These include market external debt (Euro bonds and loans), bilateral and IMF loans as well as the net present value of the residual Icesave payment expected to be covered by the government.

- Baseline sovereign asset value is derived from market CDS and the constructed default barrier. Once the default barrier is constructed, baseline sovereign asset value can be derived based on the relationships between assets and liabilities, and asset volatility which is computed from the market CDS spreads. For the implied

\footnotetext{
${ }^{4}$ The market value of sovereign assets is not directly observable and must therefore be estimated. The approach adopted here estimates sovereign asset value indirectly from information on observable value - market CDSof the liability side of the balance sheet, relying on the relationship between assets and liabilities. Market information provides the leverage ratio and asset volatility needed to compute the implied sovereign assets.
} 
sovereign asset calculation, the baseline model for Iceland is calibrated to fit with 5-year CDS in May 2010 (the most liquid series).

25. Given the balance sheet, simulations can be used to illuminate risks. For each simulation, the increase/decrease in sovereign asset value compared to the baseline could be translated into a change in the market CDS be employing the same relationship used to estimate sovereign assets. Changes in sovereign asset value could be due to potential losses from contingent liabilities (higher put option value), changes in the net fiscal assets due to fiscal policy, or changes in the terms of the debt.

\section{There are three risk scenarios of particular interest for Iceland:}

- Variations in the fiscal consolidation path. The government has set an ambitious consolidation plan for the medium term to bring Iceland's debt level down. Since the market expectation of the consolidation path is embedded in the present CDS level, a slower consolidation could raise perceived risk on Iceland's ability to repay its external obligations. Two scenarios are considered: (i) the medium-term consolidation path in the authorities revised medium-term consolidation plan; and (ii), for illustrative purposes, a much less ambitious plan ("consolidation fatigue").

Assumptions on primary balances, in percent of GDP

\begin{tabular}{|l|l|l|l|l|l|}
\hline Scenario & 2011 & 2012 & 2013 & 2014 & 2015 \\
\hline $\begin{array}{l}\text { Baseline: Second } \\
\text { review }\end{array}$ & 1.3 & 4.3 & 6.4 & 6.9 & 6.9 \\
\hline $\begin{array}{l}\text { Revised MT } \\
\text { consolidation plan }\end{array}$ & 0.6 & 3.9 & 6.0 & 6.0 & 6.0 \\
\hline $\begin{array}{l}\text { Consolidation } \\
\text { fatigue }\end{array}$ & 0.6 & 0.6 & 0.6 & 0.6 & 0.6 \\
\hline
\end{tabular}

Source: Staff estimates.

- Icesave outcomes. Gross Icesave obligations amount to about 40 percent of GDP and are expected to be repaid over time mainly through asset recovery. The residual obligations would be borne by the government, according to an August 2009 agreement. This amount could vary, depending on the terms and conditions of the Icesave loan (i.e. interest rate and grace period) and the deviation from the assumed asset recovery rate and path. Lower recovery would imply higher burden on the government, and consequently higher sovereign risk. Three scenarios are considered: (i) an agreement with a lower interest rate and a grace period; (ii) the same, except with a lower asset recovery rate; (iii) the same, except with a higher asset recovery rate; and (iv) terms and conditions of the August 2009 agreement with a lower asset recovery rate. 
Assumptions on Icesave outcomes

\begin{tabular}{|l|l|l|}
\hline Scenario & \multicolumn{1}{|c|}{ Loan terms and conditions } & Asset recovery rate \\
\hline 1 & $\begin{array}{l}\text { Two year grace period and interest rate of } \\
\text { LIBOR }+275 \text { bps }\end{array}$ & 88 percent (baseline) \\
\hline 2 & $\begin{array}{l}\text { Two year grace period and interest rate of } \\
\text { LIBOR }+275 \text { bps }\end{array}$ & 50 percent \\
\hline 3 & $\begin{array}{l}\text { Two year grace period and interest rate of } \\
\text { LIBOR }+275 \text { bps }\end{array}$ & 100 percent \\
\hline 4 & $\begin{array}{l}\text { Fixed interest rate of 5.55 percent with no grace } \\
\text { period }\end{array}$ & 50 percent \\
\hline
\end{tabular}

Source: Staff estimates.

- Contingent liabilities from public enterprises. The corporate sector analysis suggested that this sector could produce contingent liability risks for the government. As noted earlier, public enterprises in the energy-intensive industry have sizable external debts that are guaranteed by the government. Most of their cash flows go into debt servicing as they are highly indebted. The equity ratios for these companies are relatively lower than industry standards and they are subject to key risks, including exposure to commodity price movements (to which their revenues are tied), and interest rate risks as they rollover their floating rate debts. A higher risk premium would also lower their prospects considerably as power projects rest on low margins. Mitigating factors include commodity price hedges and some interest swaps. To illuminate the risk they pose, a shock of 10 percentage point increase of the aluminum price volatility is considered ${ }^{5}$. The resulting change in the guarantee value, or the value of the potential losses the government could incur, compared to the baseline is subtracted from the baseline implied sovereign asset of Landsvirkjun, the national power company. A revenue shock is also assumed to reduce Landsvirkjun's implied asset value by 30 percent.

\footnotetext{
${ }^{5}$ In this application, a CCA balance sheet is constructed for Landsvirkjun. The default barrier is constructed from its external debt obligations. Because Landsvirkjun is not listed and has no market CDS, the implied asset value is calculated using the median market leverage of global electric utilities group and asset volatility of a sample of large aluminum companies. A baseline value of guarantee from the government is derived. This value is assumed to be embedded in the sovereign CDS. Median leverage of the global electric power group (at 43 percent) and asset volatility of aluminum companies (at 30 percent) is obtained from Creditedge. Global aluminum (LME) price is used for simulation purpose. The size of the shock is slightly larger than two standard deviations of annualized daily change in LME price from 2000 to May 2010 which is about 8 percent.
} 


\section{Simulations suggest that sovereign risk, and by implication external} vulnerability, is most sensitive to changes in fiscal policy and Icesave outcomes:

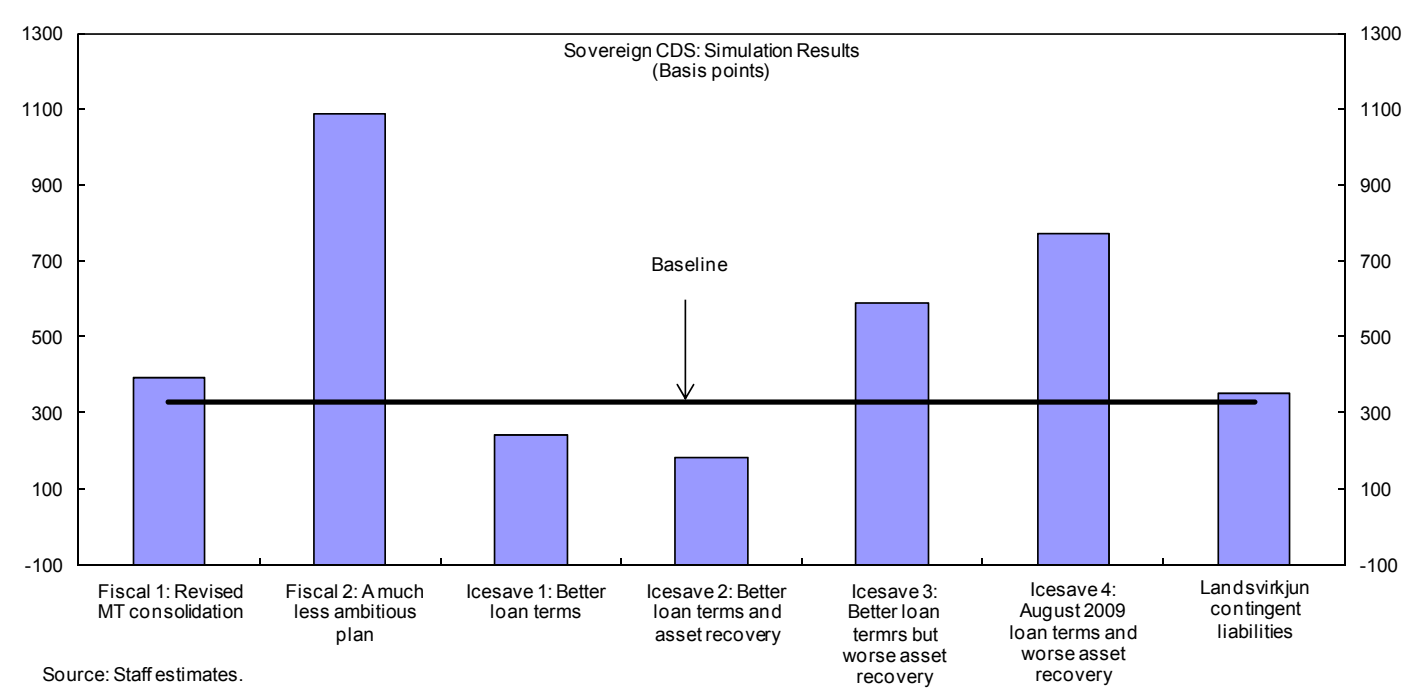

- A small change in the fiscal consolidation path, would have a moderate impact on CDS spreads of $70 \mathrm{bps}$, suggesting no meaningful impact on sustainability. However, a less ambitious path could have a very significant impact of almost 760 bps. Under this shock, external debt sustainability would not hold, pointing to the absolute necessity of continuing adjustment efforts.
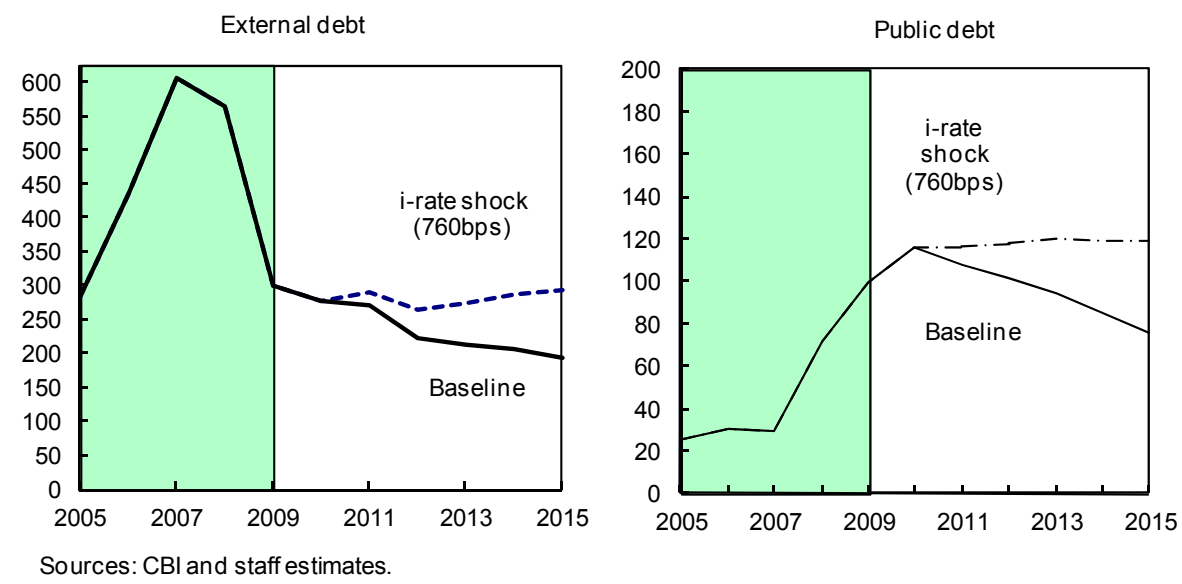

- Icesave outcomes could give a wide range of change in sovereign risks from a drop of $150 \mathrm{bps}$ to an increase of $450 \mathrm{bps}$, depending on the assumptions on asset recovery and Icesave loan terms. Of note, a low asset recovery shock would have a very significant impact on debt dynamics. Both external debt and public debt could stall at high levels, leaving the country very vulnerable to other shocks. 
Worse Icesave terms and asset recovery
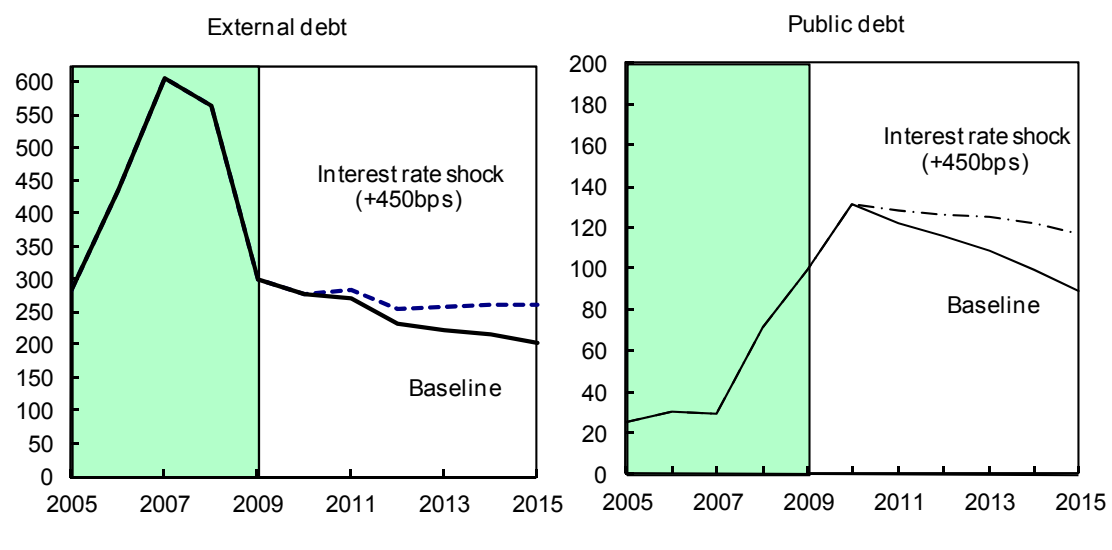

Sources: $\mathrm{CBl}$ and staff estimates.

However, under the scenario where Iceland gets better Icesave loan terms and asset recovery is higher than the baseline, the sovereign risk premium would drop as much as $150 \mathrm{bps}$. This would imply a much faster reduction in both external and public debt. External debt would reach about 170 percent of GDP by 2015 while public debt would reach 60 percent of GDP by 2015 .

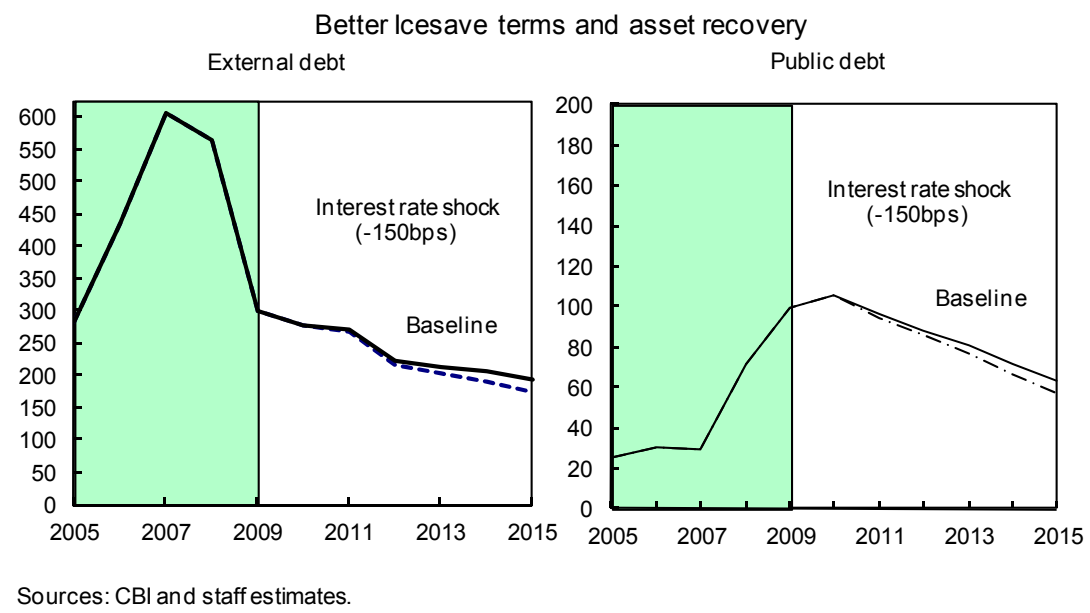

- $\quad$ The contingent liability from the national power company is not expected to be large and would therefore only raise the sovereign CDS by about 25 bps. External sustainability would be preserved.

\section{Contagion risks/spillover analysis}

28. Interest rate risk can also arise through shifts in the global risk premium. To address Iceland's vulnerability to external credit market shocks, the spillover from shocks to sovereign spreads can be estimated. Following Caceres, Guzzo and Segoviano (2010), a measure of spillover is constructed as a probability of distress of a country conditional on other countries becoming distressed. The methodology uses the marginal probabilities of 
defaults that are extracted from individual CDS spreads and obtains the joint probability of default generated from a model developed by Segoviano (2006) which is a nonparametric methodology used to estimate the multivariate empirical distribution. Countries in consideration include Iceland, 10 euro area countries, US, UK, Japan and Sweden.

\section{The results show that Iceland has been much less affected by the recent euro} area sovereign debt distress compared to other countries. Up to the fall of 2009, Iceland was affected by external events in the sovereign markets as much as other countries were. However, since then, the spillover has been much less. The timing coincides with the strengthening of the capital controls administration, while another factor may well be Iceland's earlier fiscal consolidation efforts, which began in earnest at this point. This suggests that Iceland's present policy framework has played an important insulating role, and has helped reduce external vulnerabilities.

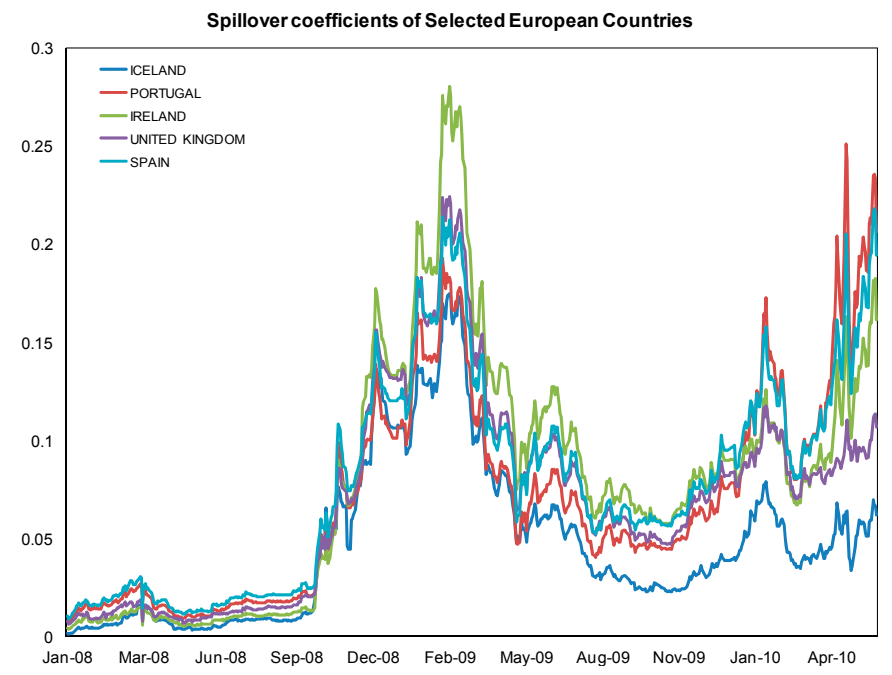

\section{Conclusion}

\section{A closer look into Iceland's external position reveals mitigating factors for}

external vulnerabilities. Traditional external DSA suggests that Iceland's external debt is sustainable but is vulnerable to depreciation shock. However, sizable positions related to multinationals' FDI help mitigate liquidity and solvency risks, while most other corporate loans are hedged through foreign currency income and assets. The effect of the depreciation shock in the DSA may therefore be overstated. In addition, the external debt path remains on a downward trajectory with risk premium shocks from various sources. Using the CCA framework for simulation purpose, Iceland's risk premium is most sensitive to Icesave settlement outcomes and the fiscal consolidation path. Contingent liabilities from the national power company do not seem to pose large risks. Iceland has also been shielded from the recent euro area sovereign debt distress contagion, pointing to a benefit of Iceland's present policy framework, including the temporary capital controls and early fiscal consolidation efforts. 


\section{REFERENCE}

Allen, M., C. Rosenberg, C. Keller, B.Setser and N. Roubini, 2002, "A Balance Sheet Approach to Financial Crisis," IMF Working Paper No. 02/210 (Washington: International Monetary Fund).

Brukoff, P. and B. Rother, 2007, "FDI May Not Be as Stable as Governments Think," IMF Survey (Washington: International Monetary Fund).

Caceres, C., V. Guzzo and M. Segoviano, 2010, "Sovereign Spreads: Global Risk Aversion, Contagion or Fundamentals?” IMF Working Paper No. 10/120 (Washington: International Monetary Fund).

Lane, P. and G. Milesi-Ferretti, 2005, “A Global Perspective of External Positions,” IMF Working Paper No. 05/161 (Washington: International Monetary Fund).

Gapen, M., D. Gray, C. H. Lim, and Y. Xiao, 2005, Measuring and Analyzing Sovereign Risk with Contingent Claims, IMF Working Paper No. 05/155 (Washington: International Monetary Fund).

Gray, D. and S. Malone, 2008, Macrofinancial Risk Analysis, (London: Wiley Finance).

Gray, D., Merton, R, Bodie Z., 2008, New framework for measuring and managing Macrofinancial risk and financial stability, Harvard Business School Working Paper No. 09-015 (Cambridge: Harvard Business School).

Habib, M., 2010, Excess returns on net foreign assets: the exorbitant privilege from a global perspective, ECB Working Paper No. 1150 (Frankfurt: European Central Bank).

Landsvirkjun, 2009, Annual Report. http://www.landsvirkjun.com/media/enska/finances/Annual report 2009.pdf

Merton, R.C., 1973, “Theory of Rational Option Pricing," Bell Journal of Economics and Management Science, 4 (Spring): 141-83.

Merton, R.C., 1974, “On the Pricing of Corporate Debt: The Risk Structure of Interest Rates," Journal of Finance 29, pp. 449-70.

Segoviano, M. (2006). “Consistent Information Multivariate Density Optimizing Methodology”. Financial Markets Group, Discussion Paper No. 557. 


\section{OVERCOMIng CONSTRAINTS To GrowTH ${ }^{1}$}

\section{A. Introduction}

1. Export led growth is essential to help Iceland address its public and external debt challenges. Fiscal adjustment is a necessary condition for a resolution of a public debt sustainability challenge. However, growth is typically ex-post the most important contributor to large declines in public debt (IMF WEO, 2004). The need for a growth strategy has figured prominently in discussions with social partners about Iceland's medium-term fiscal consolidation strategy. Looking to the external debt side, a current account surplus is necessary to reduce debt, but import compression, and the GDP declines necessary to generate this, work against a reduction of debt ratios. Export-led growth thus helps a country build positive public and external debt dynamics.

2. However, the narrow highly specialized structure of Iceland's economy appears to place a constraint on growth. The narrow structure of exports and the size of domestic economy make the creation of new industries (and export products) more difficult than in a more diversified economy. And there appear to be constraints to scaling up existing production and exports. This supply-side rigidity also leaves the economy vulnerable to global market conditions in the industries in which it operates.

3. This paper examines constraints imposed by the structure of the Icelandic economy, and how they can be overcome. Section II documents the production and export structure. Section III examines whether it may constrain growth, using methodologies developed in Hausmann, Hwang and Rodrik (2007) and Hausmann and Klinger (2006), and then discusses the potential for new exports and for expanding existing exports. In this context, risks to growth are also delineated.

\section{B. The structure of the Icelandic economy}

4. Iceland's production and export base has been recognized as relatively small and narrow. Both Icelandic scholars and external observers point to the dominance of fishery and aluminum in the export basket (Gylfason, 2004; Invest in Iceland Agency, 2005; OECD 2001); and standard measures confirm that exports diversification is relatively low (Figure 1). Similarly, openness has been and remains low for such a small economy (Breedon and Pétursson, 2004).

\footnotetext{
${ }^{1}$ Prepared by Wojciech Maliszewski.
} 
Figure 1. Iceland: Trade openness and export concentration vs. country size.
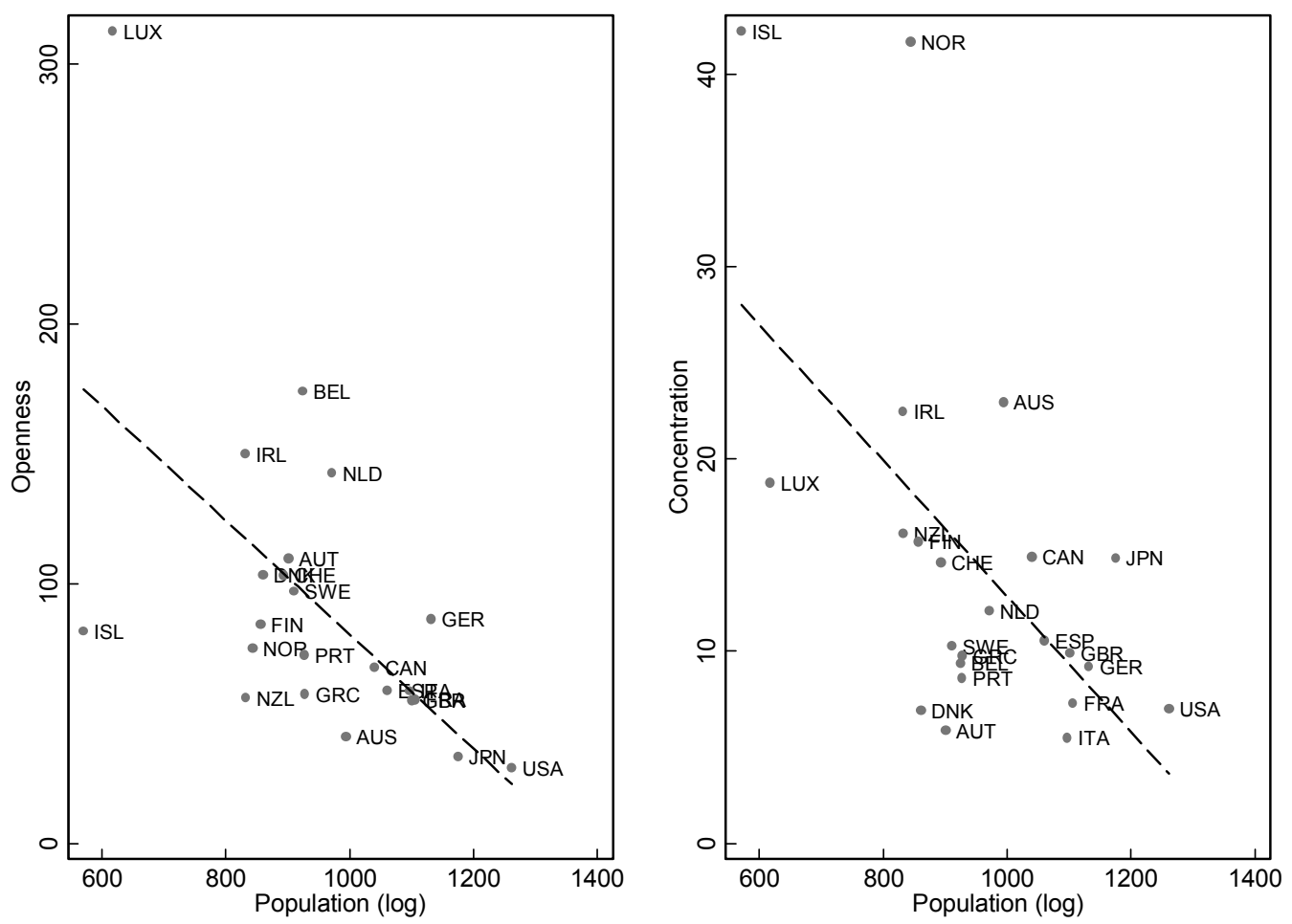

Notes: OPEN = (Export+Import)/GDP; export concentration is measured by Herfindahl-Hirschmann export product concentration index; IPOP = $\log$ (population)

Sources: PWT, WB WDI, WB World Trade Indicators.

\section{Goods exported from Iceland are on average less 'sophisticated' than suggested}

by its level of development (Figure 2). An index of product sophistication for Iceland is less than for other Nordic countries, and the difference is persistent and growing over time (see Box 1 about details on the derivation of the index). The main contributions to the index come from the mainstay of Icelandic exports: fishery and aluminum (Table 1). Countries relying on exports of these products are typically poorer than Iceland, hence the low overall value of the index. However, it is important to note that the large natural resource base combined with the small population still generates a relatively high per capita GDP in Iceland. The contribution from orthopedic devices and medicaments, which can be attributed to two large multinationals operating from Iceland, is noticeable despite a relatively low volume of these exports. ${ }^{2}$ These R\&D-intensive exports are typically associated with countries with high per capita income.

\footnotetext{
${ }^{2}$ Icelandic R\&D-intensive sectors own large offshore production facilities. Our export sophistication measure, which does not take the offshore production into account, may therefore underestimate sophistication of the Iceland-owned production structure.
} 


\section{Box 1: Export sophistication and open forest measures}

Export sophistication assesses the productivity level associated with the country's export structure: countries with a higher per capita GDPs tend to produce goods associated with higher productivity levels. The index of sophistication by Hausmann et al. (2007) first measure the productivity associated with a single tradable good $i$ (PRODY) as a weighted average of GDP per capita of each country exporting this good:

$$
\operatorname{PRODY}_{i, t}=\sum_{c} \frac{\frac{x v a l_{i, c, t}}{X_{c, t}} Y_{c, t}}{\sum_{c} \frac{x v a l_{i, c, t}}{X_{c, t}}}
$$

Where $Y_{c}$ is GDP per capita of country c, weighted by country's c comparative advantage (RCAdefined above with $x v a l_{i, c, t}$ equals exports of good i by country $\mathrm{c}$ in year $\mathrm{t}$ and $X_{c}$ is total exports by country c). Productivity level associated with the total country's export basket is derived as an exportweighted average of productivities associated with individual goods exported by the country:

$$
E X P Y_{c, t}=\sum_{i} \frac{x v a l_{i, c, t}}{X_{c, t}} P R O D Y_{i, t}
$$

Open forest summarizes the degree of relatedness of the current export baskets to products associated with high productivity, which are not yet exported by the country. It formalizes the intuitive idea that the ability of a country to produce a product depends on its ability to produce other ones. Hausmann and Klinger (2006) construct the measure of open forest by first establishing 'distances' between any two tradable products, based on the frequency of countries in the world exporting both products. The inverse measure of the distance between goods $i$ and $\mathrm{j}$, called proximity, is:

Where for any country c:

$$
\varphi_{i, j, t}=\min \left\{P\left(x_{i, t} \mid x_{j, t}\right), P\left(x_{j, t} \mid x_{i, t}\right)\right\}
$$

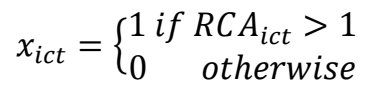

Hausmann and Klinger (2006) then define a 'density' around a single product as the sum of all paths (distances) leading to the product in which the country is present, scaled by the total number of paths leading to that product:

$$
\text { density }_{i c t}=\frac{\sum_{k} \varphi_{i k t} x_{c k t}}{\sum_{i} \varphi_{i j t}}
$$

'Open forest' is defined as the above-defined density aggregated to the country level, weighted by productivity levels (PRODY) associated with goods not yet exported by the country:

$$
\text { open forest }_{c t}=\sum_{i} \sum_{j}\left[\frac{\varphi_{i j t}}{\sum_{i} \varphi_{i j t}}\left(1-x_{c j t}\right) x_{c i t} P R O D Y_{j t}\right]
$$


Figure 2. Iceland: Export sophistication (EXPY) and per capita GDP
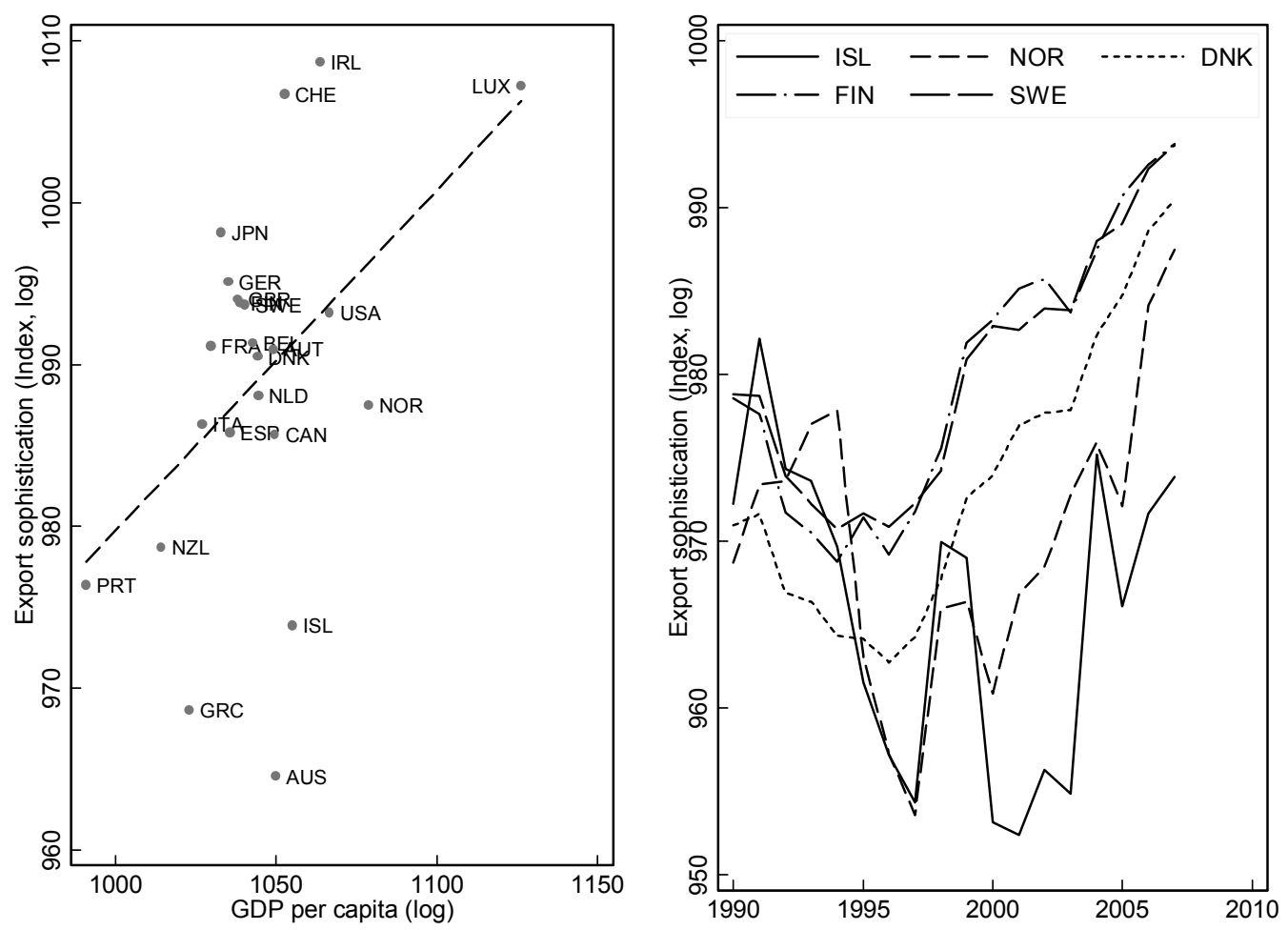

Source: PWT, Comtrade and staff calculations.

Notes: Index of export sophistication as defined in Box 1.

Table 1. Iceland: Contribution to export sophistication (EXPY).

\begin{tabular}{lrrr}
\hline & $\begin{array}{c}\text { Export value } \\
\text { (USD) }\end{array}$ & $\begin{array}{c}\text { Related } \\
\text { productivity } \\
\text { (PRODY) }\end{array}$ & $\begin{array}{c}\text { Export } \\
\text { sophistication } \\
\text { (EXPY) }\end{array}$ \\
\hline Aluminium and aluminium alloys, unwrought & $1,255,459$ & 17,490 & 5,657 \\
Fish fillets, frozen & 562,836 & 20,316 & 2,946 \\
Fish, dried, salted or brine; smoked fish & 390,192 & 16,755 & 1,684 \\
Flours, meals and pellets of fish, etc & 163,110 & 17,891 & 752 \\
Fish fillets, fresh or chilled & 237,411 & 10,334 & 632 \\
Fish, fresh (live/dead) or chilled (excluding fillets) & 199,014 & 12,066 & 619 \\
Fish, frozen (excluding fillets) & 268,207 & 8,794 & 608 \\
Medicaments (including veterinary medicaments) & 89,606 & 25,270 & 583 \\
Orthopaedic appliances, surgical belts and the like & 59,077 & 32,569 & 496 \\
Crustaceans and Mulluscs, prepared or preserved & 92,695 & 20,578 & 491 \\
Fats and oils of fish and marine mammals & 65,448 & 22,790 & 384 \\
Ferro-alloys & 124,205 & 9,698 & 310 \\
\hline
\end{tabular}

Source: PWT, Comtrade and staff calculations. 


\section{Iceland's export bundle is relatively isolated from other products for a country} at its level of development. Figure 3 plots “open forest" against per capita GDP (see Box 1 for a full explanation and derivation of the open forest concept). Empirically, higher per capita incomes are associated with more diversified economies which export goods nestled in the heart of the production space. This facilitates a further expansion of exports and growth. The Iceland production structure is dominated by a small number of goods, which is not unusual for a small economy. But the goods produced and exported by Iceland are also not strongly connected to other products.

Figure 1. Open forest and per capita GDP in OECD countries.

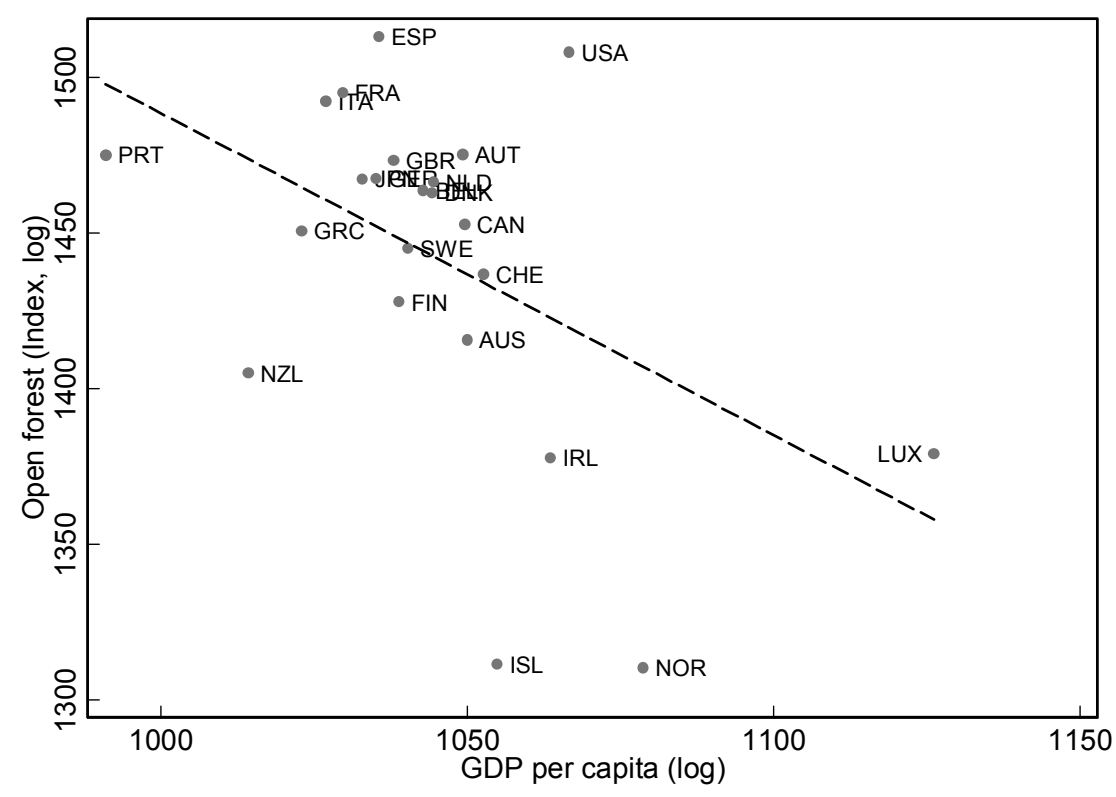

Source: Comtrade, PWT and staff calculations.

\section{Icelandic exports are concentrated in the peripheral part of the product space.}

Figure 2 show links between export products (with 4-digit SITC codes), based on 1990-2006 world trade data. ${ }^{3}$ The size of each node is determined by the share of a product in Icelandic exports in 2007. The two main product groups - fisheries (large circles in the top of the graph with SITC codes 034-037) and aluminum products (SITC code 6841) — are relatively disconnected from the core of the product space. The expansion of the aluminum sector in the past decade makes it now a dominant export product, gradually displacing fishery as the largest exporter. The two sectors dwarf all other exports, despite some expansion in the exports of machinery, medicaments, and orthopedic appliances.

\footnotetext{
${ }^{3}$ Hausmann and Klinger (2006) generate a map of the product space by first creating the 'maximum spanning tree' by taking the one strongest connection for each product that allows it to be connected to the entire product space, and then color-coding the linkages between products depending on their proximity.
} 
Figure 2. Iceland: Product space in 2007.

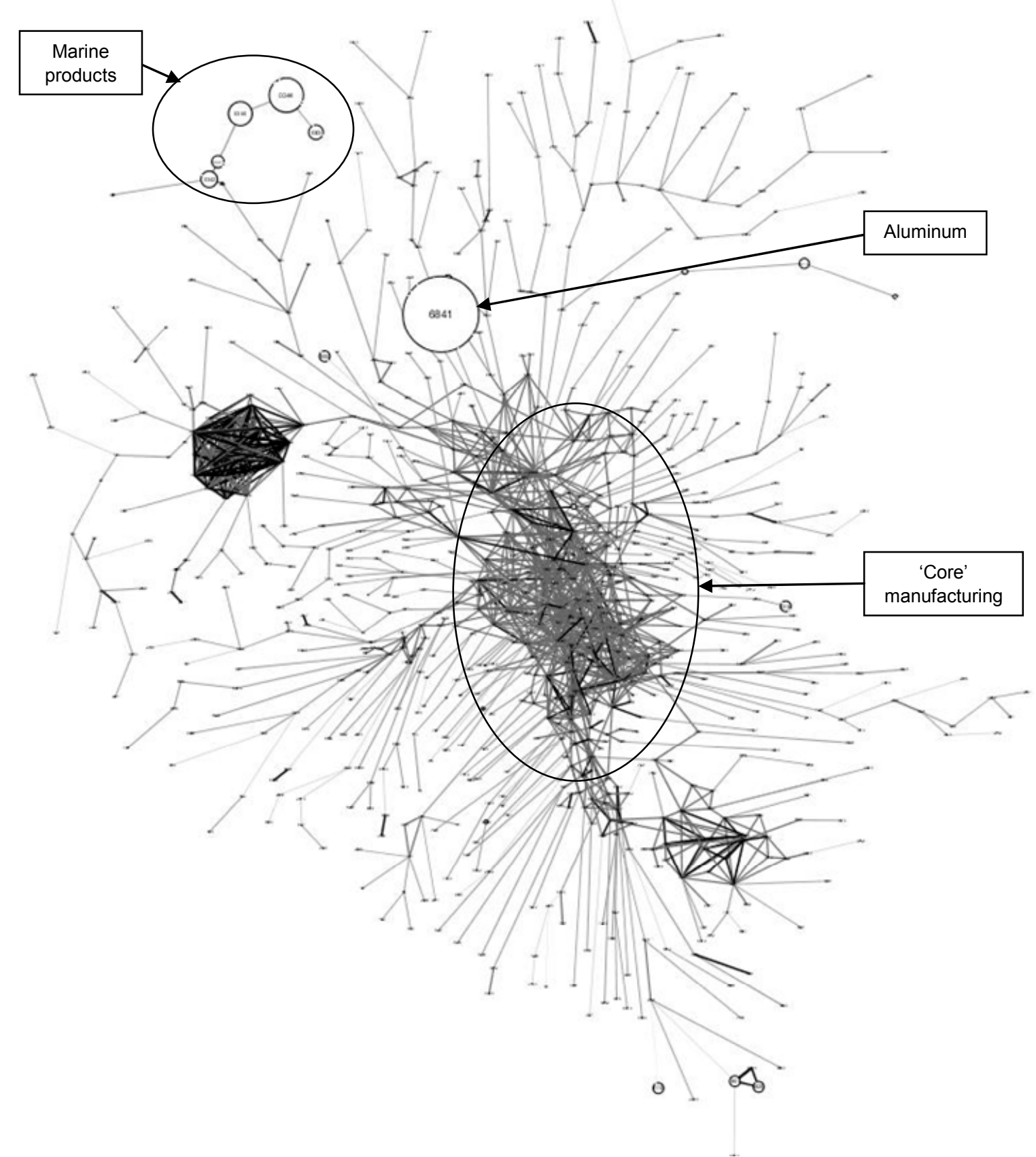

Source: PWT, Comtrade and staff calculations using methodology developed by Barabasi et al. (forthcoming). Notes: Darker links indicate closer proximities. 


\section{Is Iceland's economic structure a problem?}

\section{The link between structural characteristics of the economy and growth and} export performance can be assessed with regression analysis. Based on the standard growth regression specification, GDP growth can be linked to changes in competitiveness (real exchange rate), changes in the external environment (demand in partner countries and terms-of-trade), initial conditions (GDP per capita), export sophistication (EXPY) and export potential (open forest). Following Hausmann and Klinger (2006), a regression can be specified for exports growth. For the present estimation, the data are restricted to OECD and emerging market economies, and the analysis is conducted for 1990-2007 (with time and country dummies). The earlier work of Hausmann and Klinger is also extended to a sample restricted to large current account adjustment episodes (with adjustment episode and adjustment time dummies).

9. Results suggest that structural characteristics do matter for growth (Table 2). Similar to the findings of Hausmann and Klinger, the export sophistication measure (EXPY) has a significant impact on growth. The effect appears weaker during adjustment episodes, but the difference is not statistically significant. The measure of export potential ('open forest') has in turn a significant effect on export growth, both in the full sample and in the sample restricted to current account adjustment episodes. Estimation results imply an economically significant impact of Iceland's structural characteristics. Increasing product sophistication and 'open forest' in the Icelandic economy to the level currently recorded in Finland would raise GDP growth by around $1 / 4-1 / 2$ percentage point per year, and export growth would be $1 / 2-1$ percentage point higher. 
Table 2. Product sophistication, 'open forest', and growth and export performance.

\begin{tabular}{|c|c|c|c|c|}
\hline & (1) & (2) & (3) & (4) \\
\hline VARIABLES & $\begin{array}{c}\text { Growth } \\
\text { (full sample) }\end{array}$ & $\begin{array}{c}\text { Export } \\
\text { (full sample) }\end{array}$ & $\begin{array}{c}\text { Growth } \\
\text { (crisis sample) }\end{array}$ & $\begin{array}{c}\text { Export } \\
\text { (crisis sample) }\end{array}$ \\
\hline dGDP (-1) & $\begin{array}{l}0.201^{* * *} \\
(0.0702)\end{array}$ & & & \\
\hline External demand & ${ }^{0.827}{ }^{* * *}$ & $\begin{array}{l}1.530 \text { *** } \\
(0.191)\end{array}$ & $\begin{array}{l}0.8611^{* * *} \\
(0.156)\end{array}$ & $\begin{array}{l}1.638 \text { *** } \\
(0.380)\end{array}$ \\
\hline Terms-of-trade & $\begin{array}{l}0.0513^{* * *} \\
(0.0156)\end{array}$ & $\begin{array}{l}-0.0443 \\
(0.0233)\end{array}$ & $\begin{array}{r}0.0135 \\
(0.0317)\end{array}$ & $\begin{array}{l}-0.0217 \\
(0.0342)\end{array}$ \\
\hline dREER (-1) & $\begin{array}{l}-0.0283^{* *} \\
(0.0135)\end{array}$ & $\begin{array}{l}-0.0339 \\
(0.0502)\end{array}$ & $\begin{array}{r}-0.0219 \\
(0.0197)\end{array}$ & $\begin{array}{l}0.0255 \\
(0.109)\end{array}$ \\
\hline $\operatorname{IEXPY}(-1)$ & $\begin{array}{l}0.04922^{* * *} \\
(0.0168)\end{array}$ & $\begin{array}{r}0.0230 \\
(0.0161)\end{array}$ & $\begin{array}{l}0.0345 \text { ** } \\
(0.0153)\end{array}$ & $\begin{array}{l}0.00917 \\
(0.0349)\end{array}$ \\
\hline $\log ($ Open forest)(-1) & $\begin{array}{r}0.00899 \\
(0.00633)\end{array}$ & $\begin{array}{l}0.01622^{* * *} \\
(0.00490)\end{array}$ & $\begin{array}{r}-0.000192 \\
(0.00550)\end{array}$ & $\begin{array}{l}0.0181^{* *} \\
(0.00898)\end{array}$ \\
\hline per capita GDP(-1) & $\begin{array}{l}-0.04466^{* * *} \\
(0.0142)\end{array}$ & $\begin{array}{l}-0.0141^{* * *} \\
(0.00482)\end{array}$ & $\begin{array}{l}-0.0185^{* * *} \\
(0.00515)\end{array}$ & $\begin{array}{l}-0.0208 \text { ** } \\
(0.0106)\end{array}$ \\
\hline Constant & $\begin{array}{l}-41.31 \text { ** } \\
(16.12)\end{array}$ & $\begin{array}{r}-9.968 \\
(16.31)\end{array}$ & $\begin{array}{r}-20.59 \\
(20.95)\end{array}$ & $\begin{array}{r}-3.140 \\
(25.59)\end{array}$ \\
\hline Observations & 1100 & 1112 & 332 & 326 \\
\hline $\begin{array}{l}\text { Number of id } \\
\text { Number of episodes }\end{array}$ & 48 & 47 & 72 & 71 \\
\hline
\end{tabular}

Source: Staff calculations.

Notes: Robust standard errors in parentheses; ${ }^{* * *} p<0.01,{ }^{* *} p<0.05,{ }^{*} p<0.1$

\section{Overcoming the economic structure constraints}

\section{Diversification}

10. Techniques have been developed to identify likely routes to diversification.

Hausmann and Klinger (2008) propose a measure of 'strategic value' of every good not currently exported: They then calculate what would happen to 'open forest' if that good were added to the export basket. For products strongly connected to a large number of valuable goods not currently exported by a country, it would result in a significant expansion of the 'open forest'. Identifying goods with a high 'strategic value' which are close to the current production structure may help identifying valuable production opportunities.

11. For Iceland, there appears to be two broad routes to diversification: (Table 3):

- High R\&D industries. These would build on human capital and the existing R\&D potential, which provide a natural path to the expansion of high-value-added manufacturing. Examples include manufacturing of professional and scientific 
instruments, and measuring and controlling equipment, which are connected to products already exported from Iceland (such as medical equipment) and have a high strategic value. Although not included in the analysis, IT and more generally technology-related services are related and promising avenues for expansion, as illustrated by the vibrant game software industry operating from Iceland.

- $\quad$ Energy-intensive sectors. These would build on the energy resource endowment of the Icelandic economy, but represent industries offering more potential for moving towards the 'dense' part of the product space. The expansion in this group offers a potential to further tap energy resources, but potentially also to add more value to the export of energy resources (examples include a further expansion of production of non-ferrous metals and manufacture of fabricated metal products).

Table 3. Iceland: Industries with high strategic value close to the existing production

\begin{tabular}{ll}
\hline \multicolumn{1}{c}{ ISIC sector } & Strategic value \\
\hline Manufacture of machinery except electrical & 102069.2 \\
Manufacture of professional and scientific, and measuring and controlling equipment & 81752.5 \\
Manufacture of electrical machinery apparatus, appliances and supplies & 71375.2 \\
Non-ferrous metal basic industries & 50710.4 \\
Manufacture of transport equipment & 30886.5 \\
Manufacture of plastic products not elsewhere classified & 30831.1 \\
Manufacture of wearing apparel, except footwear & 30754.0 \\
Other Manufacturing Industries & 30448.7 \\
Manufacture of fabricated metal products, except machinery and equipment & 20476.0 \\
Food manufacturing & 20251.2 \\
Manufacture of other non-metallic mineral products & 20240.8 \\
Iron and steel basic industries & 10370.6 \\
Printing, publishing and allied industries & 10352.0 \\
Manufacture of textiles & 10346.6 \\
Unclassified & 10104.5 \\
Manufacture of other chemical products & 10028.2 \\
Agriculture and livestock production & 9984.6 \\
Manufacture of glass and glass products & 9982.7 \\
\hline
\end{tabular}

Source: UN Comtrade.

Notes: All products not exported with RCA $>1$ in 2007, dropped those with PRODY<EXPY (see Box 1), dropped minerals, dropped those with density that is not at least 1.5 standard deviation above the mean for all of Iceland's non-exported products, combined into ISIC sectors, weighted by 2007 strategic value.

\section{To expand into these more strategic industries, the economic literature suggests that three critical elements will have to be put into place (Brenton et al., 2009):}

- $\quad$ Reduced costs of doing business. Efficient provision of 'backbone' services (education, roads, telecommunication, and energy infrastructure) has been identified as one of the key determinants of exports growth and diversification. 
- Incentives to channel resources to their most productive uses. This includes policies supporting a competitive level of exchange rate, and the removal of trade distortions to ensure that resources are not diverted to protected domestic-oriented sectors.

- $\quad$ Proactive policies to support trade. Both market and government failures may hamper the expansion of exports. Export and investment promotion agencies are often important in overcoming informational asymmetries, particularly to overcome impediments to the private sector in gaining information.

13. In Iceland, conditions to support export diversification are in place, although some constraints are also apparent:

- Iceland's infrastructure is efficient and well-developed, but expanding it may prove difficult. The development of new energy-intensive industries would require an expansion in energy supply. However, environmental considerations impose some limits, as do restrictions on foreign investments (the severest among high-income OECD countries) (Figure 5).

- $\quad$ The exchange rate is modestly undervalued, and Iceland's trade regime is generally liberal. The exchange rate appears undervalued from the medium-term perspective (Staff Report Box). Trade distortions are generally low-tariff and nontariff barriers are among the lowest in OECD countries, but time to process export and import transactions is one of the longest (Figure 5).

- The Icelandic economy has consistently been ranked as one of the most competitive in the world. 2009/10 Global Competitiveness Report downgraded Iceland rating after the crisis, but still praises the country top-notch educational system, high levels of technological readiness and innovation, very flexible labor market and efficient infrastructure,. Similarly, the World Bank 2009 'Doing Business' survey places Iceland on $14^{\text {th }}$ position globally in the composite 'Ease of Doing Business' index. Some barriers to entrepreneurship, however, were identified in the OECD survey on product market regulations, pointing to excess administrative burden in permitting and regulations (Figure 5). 
Figure 5. World Bank Doing Business Index and Product market regulation indices.

Foreign participation in energy and fishing sectors is restricted...

FDI Restrictiveness Index

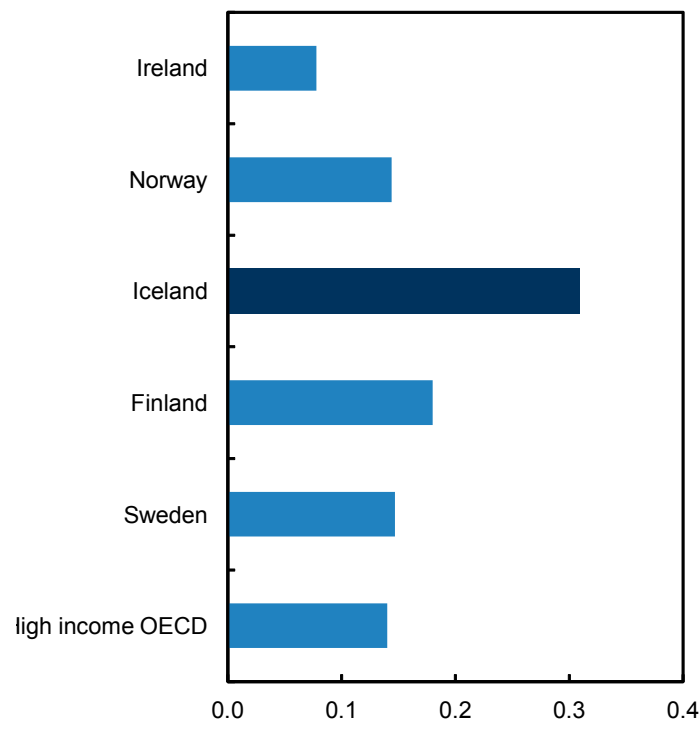

Trade regime is very liberal...

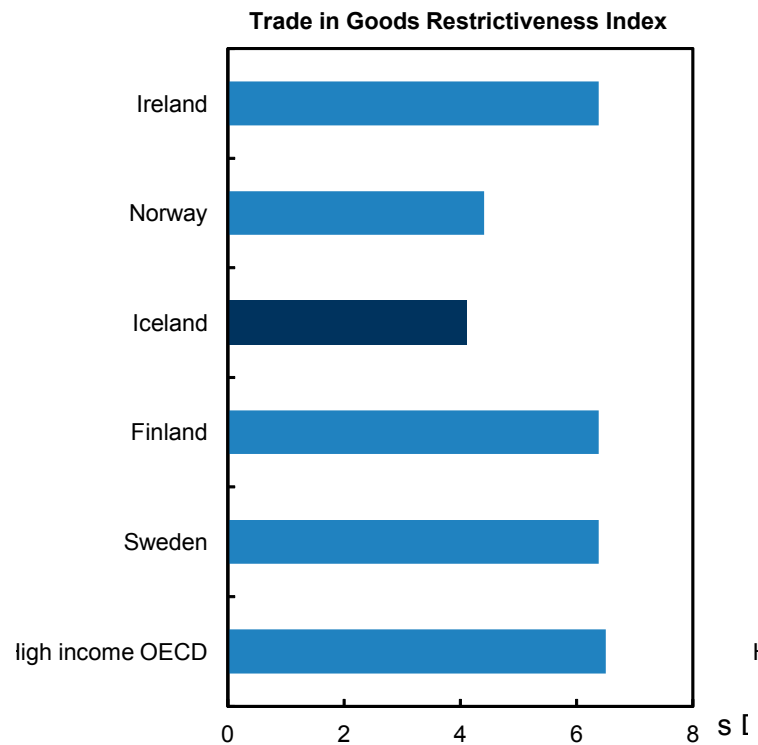

Source: WB and OECD

Notes: Higher values indicate more restrictive regime unless otherwise indicated ...and administrative barriers are worse than in other OECD countries. Barriers to Entrepreneurship

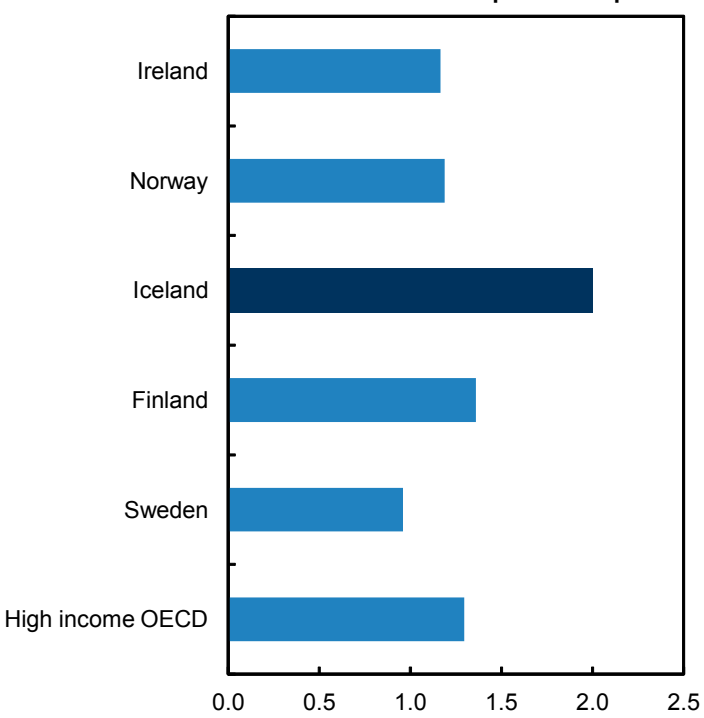

...but costs of trading are relatively high.

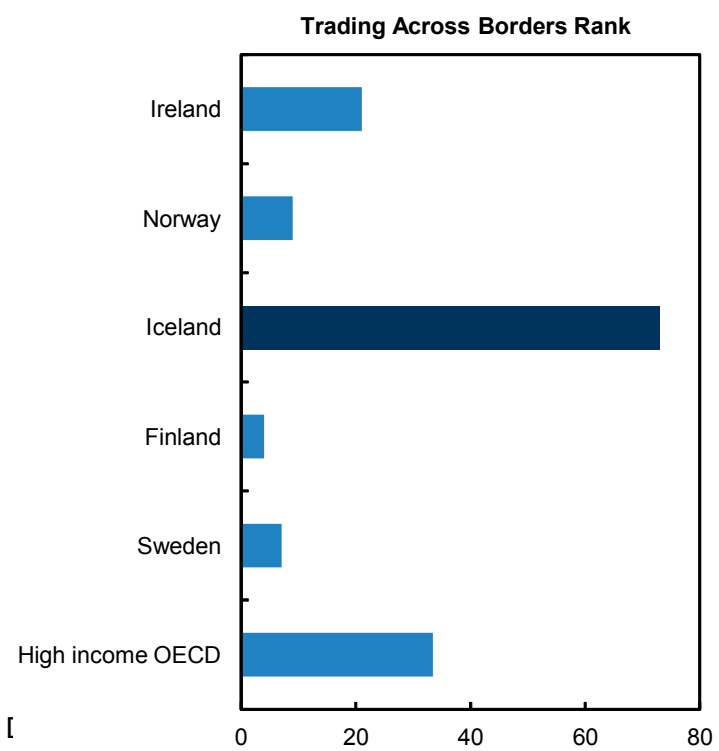


- However, financing constraints may slow investment in new industries, and need to be overcome. The collapse of the banking system and imposition of capital controls - the latter necessary to prevent a meltdown of the economy - have put a significant burden on businesses. While bigger companies are more likely to have access to both domestic and external financing, the situation is difficult for less established companies and start-ups, which are the engines of potential growth in new industries.

\section{Post-crisis export behavior points to some signs diversification is beginning.}

There has been some increase in the exports of manufacturing products and chemical industries (Figure 6), although exports shares were affected by changes in relative prices during the crisis (lower aluminum prices). Anecdotal evidence also point to some expansion of export-oriented activities other than in fishery and aluminum (e.g., production of drugs.

Figure 6. Iceland: Exports structure (in percent of total exports)

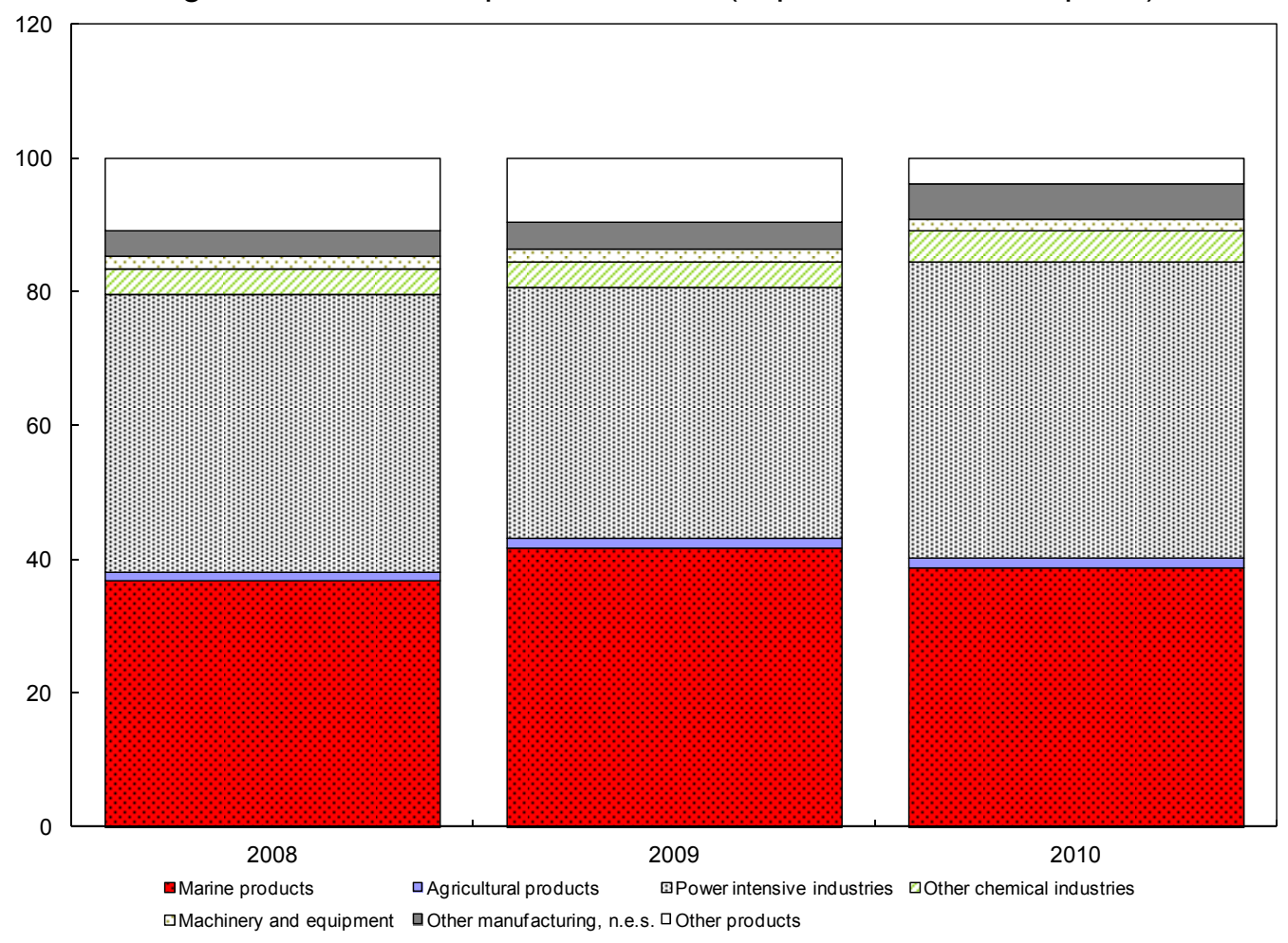

Source: Statistics Iceland.

\section{Scaling up}

15. While diversification is important, empirically, most export expansion comes from existing products. Several studies (Evenett and Venables, 2002; Besedes and Prusa, 2007; Amurgo-Pacheco and Pierola, 2007) show that the primary source of export growth, particularly in developing countries, has been from increases in existing exports (the intensive margin) rather than increases in new products or in old products to new markets (the extensive margin). Within the extensive margin, the export to new markets has 
accounted for most of the growth. For instance, Amiti and Freund (2007) find that only about 15 percent of China's export growth to the United States from 1992 to 2005 reflected new products. Export strategies that ignore the scope for expanding existing exports will miss important opportunities for propelling trade and growth (Brenton and Newfarmer, 2009).

\section{In Iceland, scaling up existing production and exports is not an option for every sector, and where it is, some constraints need to be overcome:}

- A substantial expansion of the fisheries does not appear feasible or desirable. Iceland maintains a quota system, which was implemented in 1986 after a period of substantial over-fishing and over-investment in the sector. The current catch is below the level reached in 1990's, and there is no indication that a sustainable catch level is on the rise. From 1945 until the introduction of the quota system, the value of capital in the Icelandic fisheries increased by over 1400 percent, while the catch value increased by only 300 percent, suggesting sharply diminishing returns to further investments.

- Still untapped renewable energy resources do allow for the expansion of energyintensive exports, but lead times are usually long. Current energy production in Iceland amounts to about $18 \mathrm{TWh}$, compared to total potential of at least $50 \mathrm{TWh}$. The history of development of the energy-intensive industry in the Reydarfjordur area illustrates the long lead times (Table 4).

Table 4. Iceland: Energy-intensive projects in the Reydarfjordur area

\begin{aligned} & \hline $1975-1976$ Norsk Hydro plans to build an aluminum smelter \\ & 1980-1985 Rio Tinto Zink plans to build a silicon metal plant. Project well on its way before it is abandoned. \\ & 1989-1990 Atlantal plans to build an aluminum smelter. Landsvirkjun starts constructions of the power plant but project suspended. \\ & 1998 Norsk Hydro plans to build an aluminium smelter. \\ & 1999 Memorandum of Understanding (MoU) signed for a 120.000 tonnes smelter and a power plant. \\ & 2000 A new MoU extends production capacity to up to 360.000 tons \\ & 2001 Environmental Impact Assessment (EIA) for the smelter and the power plant accepted \\ & 2002 Norsk Hydro abandons the project. \\ & Discussions with Alcoa begin. \\ & $\begin{array}{l}\text { MOU signed between the Government of Iceland, Landsvirkjun and Alcoa. } \\ \text { Project approved by Althingi }\end{array} \\ &$ The Planning Agency rules that a new EIA for the smelter not needed \\ & 2003 Construction permits for the power plant issued by the municipal authorities \\ & Energy supply contract signed and construction of the power station begins \\ & 2004 Construction of the smelter starts \\ & 2005 Supreme Court rules that the smelter should be subject to a new EIA \\ & 2006 The Planning Agency concludes the ElA for the smelter \\ & 2007 First metal produced \\ & 2008 Full production capacity \\ & \hline\end{aligned}


17. The economic impact of expanding existing energy-intensive export capacity is potentially large, pointing to a need to better secure outcomes. The macroeconomic impact of scaling up can be evaluated via model-based simulations based on the Central Bank of Iceland QMM model. ${ }^{4}$ In the simulation exercise we assume a cancelation of projects currently in the pipeline, a 200 basis points increase in the external risk premium following the cancelation, and a small increase in emigration, reducing labor force and potential output (both mechanisms are added exogenously to the model). The results suggest that cancelation of planned energy-intensive sector projects could have a significant macro impact (Figure 8). The cancelation would: (i) deepen the post-crisis recession; (ii) depreciate the exchange rate (also through the effect of higher risk premium); (iii) reduce exports and imports (the latter on the basis of exchange rate depreciation and lower input imports).

\section{E. Conclusions}

18. The structure of Iceland's economy does indeed create a growth challenge, which policy makers can address. International evidence suggests that a narrow production and export structure with weak links to the densest part of the production space should constrain growth potential. And there are constraints to scaling up Iceland's existing production. Still, Iceland has room to support export diversification into strategic goods related to its comparative advantage, for instance by maintaining a competitive exchange rate. Removing barriers to investment in "backbone" infrastructure, particularly in the energy sector would also support a scaling up of existing production, addressing downside risks to growth.

\footnotetext{
${ }^{4}$ The QMM model has been modified by disaggregating export and import equations compared to the original model.
} 
Figure 8. Macroeconomic impact of the cancellation of investment projects in the pipeline.
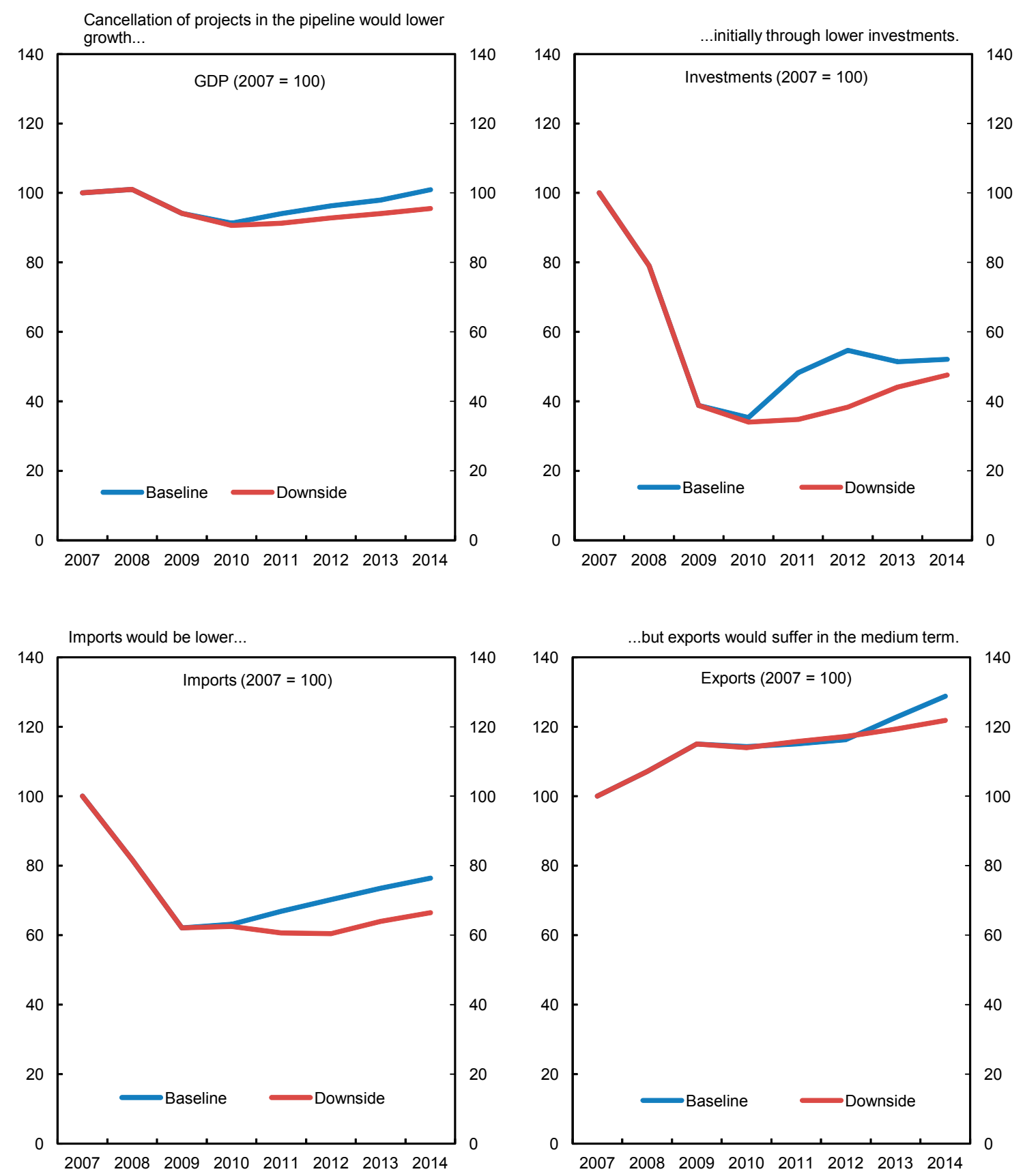

Source: Staff calculations. 


\section{REFERENCES}

Amiti, M., \& C. Freund, 2007. "An Anatomy of China's Export Growth.” Paper prepared for Global Implications of China's Trade, Investment and Growth Conference, International. Monetary Fund Research Department, April 6, 2007.

Amurgo-Pacheco, A., \& D. Pierola, 2007. "Patterns of Export Diversification in Developing Countries: Intensive and Extensive Margins." Graduate Institute of International Studies, Geneva.

Barabasi, A. \& R. Hausmann \& C. Hidalgo \& B. Klinger. "The Product Space and its Consequences for Economic Growth". Forthcoming.

Besedes, T., \& T. Prusa, 2007. "The Role of Extensive and Intensive Margins and Export

Growth.” NBER Working Paper 13628, National Bureau of Economic Research, Cambridge, MA.

Francis Breedon \& Thórarinn G. Pétursson, 2006. "Out in the cold? Iceland's trade performance outside the European Union and European Monetary Union," Cambridge Journal of Economics, Oxford University Press, vol. 30(5), pages 723-736, September.

Brenton, P., \& Newfarmer, R., (2009). "Watching More Than the Discovery Channel to Diversify Exports," In "Breaking Into New Markets: Emerging Lessons for Export Diversification", William Shaw \& Richard Newfarmer \& Peter Walkenhorst (Eds.), Washington, DC: World Bank.

Paul Brenton \& Richard Newfarmer \& William Shaw \& Peter Walkenhorst, 2009. In "Breaking Into New Markets: Emerging Lessons for Export Diversification", William Shaw \& Richard Newfarmer \& Peter Walkenhorst (Eds.), Washington, DC: World Bank.

Evenett, Simon \& Anthony Venables, 2002. "Export Growth by Developing Economies: Market Entry and Bilateral Trade." Working paper, St. Gallen University, Berne.

Ghosh, Atish R., \& Jonathan Ostry, 1994. "Export Instability and the External Balance in Developing Countries." Working Paper 94/8, International Monetary Fund, Washington, DC.

Thorvaldur Gylfason, 2004, "Economic Developments in Iceland since 1945," Lecture at a conference on Economic Affairs in the Danish Commonwealth organized by the North Atlantic Group in the Danish Parliament in Copenhagen 26 May 2004. http://notendur.hi.is/gylfason/danishparliament.ppt 
Ricardo Hausmann \& Jason Hwang \& Dani Rodrik, 2007. "What you export matters," Journal of Economic Growth, Springer, vol. 12(1), pages 1-25, March.

Hausmann, Ricardo \& Klinger, Bailey, 2006. "Structural Transformation and Patterns of Comparative Advantage in the Product Space," Working Paper Series rwp06041, Harvard University, John F. Kennedy School of Government.

Invest in Iceland Agency, 2005,"Doing Business in Iceland”, 5th edition

Gian Maria Milesi-Ferretti \& Assaf Razin, 1998. "Current Account Reversals and Currency Crisis-Empirical Regularities," IMF Working Papers 98/89, International Monetary Fund.

OECD, 2001. "Economic Survey of Iceland," OECD

Hausmann, Ricardo \& Klinger, Bailey, 2006, "Structural Transformation and Patterns of Comparative Advantage in the Product Space," Working Paper Series rwp06041, Harvard University, John F. Kennedy School of Government.

Invest in Iceland Agency, 2005,"Doing Business in Iceland”, 5th edition

Gian Maria Milesi-Ferretti \& Assaf Razin, 1998, "Current Account Reversals and Currency Crisis-Empirical Regularities," IMF Working Papers 98/89, International Monetary Fund.

OECD, 2001. "Economic Survey of Iceland," OECD 


\section{Fiscal CONSOLIDATION OPTIONS ${ }^{1}$}

\section{A. Introduction}

\section{Iceland's financial crisis burdened the country with very high public debt.}

Business cycle-related deficits, the need to recapitalize the banking system, crisis-related central bank losses, and foreign deposit insurance requirements combined to push the debt to 105 percent of GDP by end-2009 (Figure 1). ${ }^{2}$ Since the debt overhang puts fiscal sustainability at risk, ${ }^{3}$ an ambitious fiscal consolidation program is needed to set the debt ratio on a declining path.

Figure 1. Fiscal Consequences of the 2008 Crisis

(Percent of GDP)
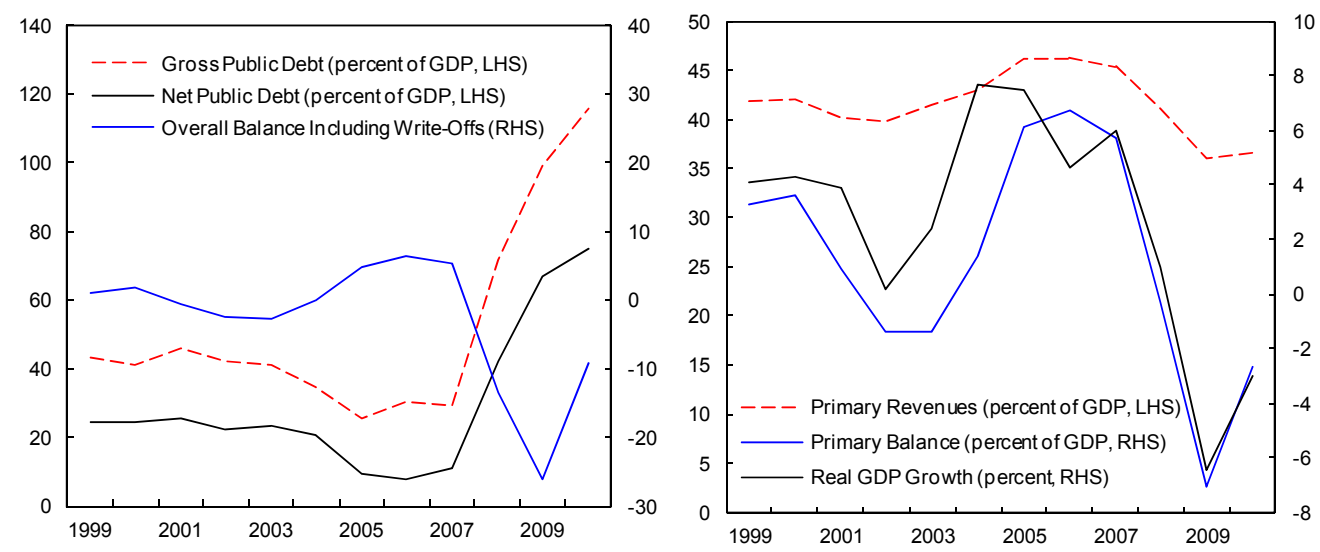

Sources: Ministry of Finance of Iceland; Statistics Iceland; and IMF staff calculations.

Notes: Write-offs include costs of central bank recapitalization, failed securities lending to commercial banks, NPV of the cost of Icesave depositor guarantees, and retroactive interest paid to new banks to compensate for late capitalization.

2. The first stage of the consolidation program is already in place. The government of Iceland took some 2 percent of GDP in policy measures during 2009, and over 5 percent of GDP in measures in 2010. All told, the primary balance has improved by about 5 percent of GDP. Revenue measures have included increases in VAT rates, excise rates, and social security contributions. On the expenditures side, transfers and capital spending have been reduced the most, but operating expenditures have also been curtailed to bring total central

\footnotetext{
${ }^{1}$ Prepared by Wojciech Maliszewski and Iva Petrova.

${ }^{2}$ The general government debt includes the net present value of Icesave-related contingent liabilities.

${ }^{3}$ See Ostry et al. (2010).
} 
government spending down by about 3 percent of GDP. Also, local governments have cut expenditure by almost $1 / 2$ percent of GDP.

3. The need for fiscal adjustment has stirred up public debate about the most appropriate course ahead. A medium-term consolidation strategy, published in July 2009, established a baseline plan. ${ }^{1}$ However, both the pace of fiscal consolidation (which is programmed to be in line with experience in other Nordic countries) and the composition of the adjustment remain under close scrutiny. Considerations affecting the choice of a fiscal adjustment mix include the desire to maintain the Nordic-type welfare state and to balance the need for public debt reductions against the need to support the economic recovery.

\section{This paper sheds light on the macroeconomic effects of different fiscal} adjustment options. We use the Global Integrated Monetary and Fiscal Framework (GIMF), calibrated to Iceland, to model fiscal consolidation under different scenarios for expenditure and revenue adjustment. The model suggests that an expenditure-oriented fiscal adjustment, especially if associated with reductions in transfers, would be modestly less detrimental to growth than a tax-based adjustment. If a more revenue-oriented consolidation is selected, a mix including a VAT increase would give room for a more export-oriented growth. As for the overall pace of fiscal consolidation, the pace now planned will protect the downward path of public debt from leveling off due to external shocks or realized contingent liabilities.

\section{B. Background: fiscal consolidation objectives and options}

5. The medium-term fiscal consolidation plan that the authorities presented to Parliament in July 2009 is appropriately ambitious. It aims to achieve: (i) a primary central government surplus by 2011; (ii) an overall central government surplus by 2013; and (iii) public debt of 60 percent in the long run. It also commits to a balanced use of revenue and expenditure measures, and a separate understanding reached with social partners suggest that revenue measures should amount to 45 percent of the needed adjustment. Creating conditions for stronger economic activity is an overarching theme of the plan. Finally, the authorities are committed to maintaining quality welfare services, including by protecting healthcare, social services, and public education.

6. Potential areas for expenditure rationalization have been identified in OECD reports , and the authorities have advanced in their implementation: ${ }^{2}$ The OECD has pointed to health care and education as areas where public spending is high by OECD and Nordic standards and cost-cutting could be implemented (Table 1).

\footnotetext{
${ }^{1}$ See Ministry of Finance of Iceland (2009).

${ }^{2}$ See OECD (2009).
} 
- In particular, OECD calculations have shown that input efficiency of the Icelandic health system is in the third quartile among all OECD countries. Should it be increased to the level of Spain — which is in the first quartile — health care spending could be reduced by 17.5 percent without compromising quality. Measures to cut expenditure by 13.2 percent have already been implemented since 2009 , and with additional measures in 2011 to cut current expenses of 4.7 percent, the recommended reforms are expected to be near completion and total 1.5 percent of projected 2011 GDP.

- $\quad$ OECD estimates have also shown that there is scope for rationalizing education spending. The input efficiency of Iceland's education system has been assessed as lower than the OECD average, and increasing it to that level would allow reducing education spending by about 21 percent without compromising outcomes. Reductions in school costs of 1.6 percent in 2009 and 7 percent in 2010 have already been implemented, and a further reduction of 5 percent in upper secondary school costs and 7.5 percent in university costs will be implemented in 2011.

7. Other areas of expenditure rationalization identified by the OECD are public sector wages, investment, and agricultural subsidies. The wage bill was reduced by 0.5 percent of GDP in 2010 and will undergo a further cut of 0.5 percent of GDP in 2011. Investment was reduced by 0.5 percent of GDP in 2010 and will be further reduced by 0.2 percent of GDP in 2011.

Table 1. Potential Areas of Expenditure Rationalization

\begin{tabular}{lcc}
\hline \multicolumn{1}{c}{ Recommendation } & In ISK billions & In Percent of 2009 GDP \\
\hline $\begin{array}{l}\text { Reduce public-sector wage bill by 5\% } \\
\text { Reduce public investment to 1\% of GDP }\end{array}$ & 10 & 0.5 \\
& 15 & 1 \\
$\begin{array}{l}\text { Introduce cost-cutting reforms in health care to raise } \\
\text { spending efficiency to the level of the first quartile }\end{array}$ & $20-25$ & 1.5 \\
$\begin{array}{l}\text { OECD-member country } \\
\text { Introduce cost-cutting reforms in education to raise } \\
\text { spending efficiency to the level of the OECD average }\end{array}$ & $20-25$ & 1.5 \\
& 10 & 0.75 \\
\hline
\end{tabular}

Source: OECD, 2009, Economic Surveys: Iceland, Volume 2009(16).

8. There is also scope for raising tax revenues. A recent IMF technical assistance mission has found that, while Iceland's tax system already yields high revenue, there is some room for greater collection. ${ }^{1}$ Iceland's tax system features relatively low rates, broad tax bases, limited cases of favorable treatment, and small opportunities for arbitrage — all

\footnotetext{
${ }^{1}$ See Escolano et al. (2010).
} 
contributing to high revenue yield and low distortionary impact. Consequently, at 34 percent of GDP, general government tax revenue is among the highest among OECD countries - as is required to fund relatively high expenditure levels. Nonetheless, there are a few areas in which improving tax efficiency could also help raise additional revenues: (i) raising or eliminating the reduced VAT rate and eliminating non-standard VAT exemptions (1.11.5 percent of GDP); (ii) improving the progressivity of the personal income tax and increasing the personal capital income tax to 20 percent (0.6-0.7 percent of GDP); (iii) increasing the fuel excise (0.3-0.5 percent of GDP); and (iv) increasing the corporate income tax $(0.1$ percent of GDP).

\section{The model}

9. The macroeconomic implications of the size and mix of fiscal adjustment can be considered using the IMF's Global Integrated Monetary and Fiscal Model (the GIMF). The GIMF is a calibrated model commonly used to assess the implications of fiscal measures on the real economy. ${ }^{1}$ The main advantage of this analysis is the granularity with which different fiscal policy instruments can be examined compared to analysis based on empirical estimations. This allows realistic fiscal policy scenarios to be modeled.

\section{The GIMF model contains three channels through which fiscal adjustment} affects the economy:

- Government spending affects aggregate demand both directly and through multiplier effects due to its effect on output and income. In addition, changes in government investment affect the productivity of private capital and labor, and magnify output responses.

- $\quad$ Taxes create distortions that affect the supply of factors of production, which in turn affects output. Changes in the level of taxation also affect aggregate demand. They have strong income and wealth effects due to consumers' finite work life and planning horizon; agents experience real and permanent wealth/income losses.

- $\quad$ Transfers generate wealth and income effects similar to changes in lump-sum taxes. In addition, the existence of liquidity constrained consumers who do not have means to smooth lifetime consumption, amplifies the impact of transfer cuts on aggregate consumption.

11. The model for Iceland is calibrated to produce a steady state similar to the present economic structure, and to generate reasonable dynamic responses to shocks:

\footnotetext{
${ }^{1}$ See Freedman et al. (2009), Kumhof et al. (2009 and 2010) and Clinton et al. (2010).
} 
- The steady-state is calibrated at the expected 2010 public debt value of 118 percent of GDP (Appendix 1). Calibrating steady-state debt at this value allows us to simulate a realistic public debt path in the following 10 years. Similarly, government expenditures on consumption and investment are calibrated to be, respectively, at $24 \frac{1}{2}$ percent and $2 \frac{1}{2}$ percent of GDP, corresponding to projected 2010 ratios according to national accounts definitions (Box 1).

- $\quad$ The model is calibrated to broadly match the impulse responses to shocks generated by the central bank's QMM model ${ }^{2}$. Thus, a 100 bps increase in monetary policy rate for one year reduces annual inflation by around 0.3 percentage point and GDP growth by 0.4 percent within the first year, mainly through the exchange rate channel. The effects of government expenditure shocks are also close to those in the central bank model - the short-run multiplier is relatively low (at 0.6 percent) because of the leakage effect through imports. Similarly, a depreciation shock (1 percent drop in exchange rate) generates a substantial increase in inflation in the first year (with the implied pass-through coefficient of about 0.2 in line with the QMM model), but also a real exchange rate depreciation leading to improvements in the trade balance. The implied imports (0.3) and exports (-0.3) elasticities with respect to real exchange changes are again close to those found in the QMM model.

\section{Box 1. Model definitions}

Government primary expenditures: The national accounts definition is used; thus, government consumption and investment are included, but not transfers to consumers.

Government primary revenues. To simplify the modeling these are taken to include interest revenues.

Government is general government (i.e. the consolidation of central and local governments). It is assumed that policy measures taken by the central government are used to achieve the targeted general government primary balance, while local government balances are unchanged.

12. The steady state model is simulated forward to establish a baseline against which to investigate alternative scenarios. Key assumptions underlying this baseline include:

- $\quad$ The fiscal consolidation entails a frontloaded 83/4 percent of GDP primary balance improvement in 2011-13, a positive primary balance in 2011, and a positive overall

\footnotetext{
${ }^{2}$ See Danielsson et al. 2009 for details of the QMM.
} 
balance in 2013. The 2013 primary balance - at 6 percent of GDP — is then maintained for 5 years to sustain the downward trend of the debt to GDP ratio to reach a long-term target of 60 percent of GDP in a 10-year horizon.

- $\quad$ The authorities use a balanced mix of revenue and expenditure measures (as agreed with social partners). Policy measures taken by 2013 are assumed permanent, and in the outer years transfers adjust automatically and remain contained to preserve the primary balance at 6 percent. Revenues are assumed to be raised through PIT in 2011, and through VAT (or other consumption taxes) in 2012-13, as these are the highest yielding potential tax policy measures. Public consumption and transfers are reduced in equal amounts in 2011-13. Public investment is reduced only temporarily in 2011 (which prevents a long-term deterioration in private sector productivity).

- To capture "post-crisis"-like effects, liquidity constrained consumers are assumed to comprise 50 percent of the population. ${ }^{3}$ These are consumers whose credit score prohibits borrowing and whose level of income prevents them from holding financial instruments.

\section{Four main alterative scenarios are used to evaluate the effect of the composition} and pace of fiscal consolidation (Appendix 2 and Table 2). The first two capture the impact of a more expenditure oriented fiscal adjustment (Scenario 1) and a more revenue-oriented fiscal adjustment (Scenario 2). A second set of scenarios analyses the size and speed of fiscal adjustment by assuming a smaller primary balance adjustment than in the baseline (Scenario 3) and a more back loaded fiscal adjustment that in the baseline (Scenario 4). All other assumptions remain as in the baseline.

Table 2. Fiscal Adjustment Scenarios

(Cumulative change in 2011-13 in percent of GDP)

\begin{tabular}{lccccc}
\hline & & \multicolumn{2}{c}{$\begin{array}{c}\text { Composition of the Fiscal } \\
\text { Adjustment }\end{array}$} & Pace of the Fiscal Adjustment \\
\cline { 3 - 6 } & Baseline & $\begin{array}{c}\text { Scenario 1 } \\
\text { Expenditure- } \\
\text { Oriented }\end{array}$ & $\begin{array}{c}\text { Scenario 2 } \\
\text { Revenue- } \\
\text { Oriented }\end{array}$ & $\begin{array}{c}\text { Scenario 3 } \\
\text { Smaller }\end{array}$ & $\begin{array}{c}\text { Scenario 4 } \\
\text { Delayed }\end{array}$ \\
\hline Primary Balance & 8.7 & 8.7 & 8.7 & 8.1 & 8.7 \\
Revenues & 2.2 & 0.7 & 4.2 & 1.9 & 3 \\
Expenditures & 6.5 & 8.0 & 4.5 & 6.2 & 5.7 \\
\hline
\end{tabular}

\footnotetext{
${ }^{3}$ A similar ratio of liquidity constraint consumers has been used in the case of upper income emerging European economies, see Allard and Muñoz (2008) and Allard et al. (2008)
} 


\section{Results}

\section{The fiscal adjustment mix}

14. Model simulations suggest that an expenditure-oriented adjustment would have a modestly less negative impact on aggregate demand than a revenue-oriented one

(Figure 2):

- Under an expenditure-based consolidation, the additional cut in public consumption and transfers of 1.5 percent of GDP in 2011-13 relative to the baseline reduces taxinduced distortions, raising potential output. As a result, cumulative GDP growth is about one-third of a percentage point higher compared to the baseline by 2014 and inflation is lower by about $3 / 4$ percent in 2011-15, which allows for lower real interest rates. The higher permanent income and lower interest rates open room for private demand (Figure 3). Private consumption is expected to be about 1 percent of GDP higher by 2015, and under perfect foresight, firms raise investment already in 201113. However, a somewhat more appreciated real effective exchange rate, results in a slightly more negative trade balance compared to the baseline (by about $1 / 2$ percent of GDP).

- Under a revenue-oriented consolidation tax distortions reduce growth prospects. Cumulative GDP growth is about $1 / 2$ percent lower than under the baseline by 2014 and about $3 / 4$ percent lower than under a more expenditure-oriented consolidation. Meanwhile, the inflation rate is nearly 1 percentage point higher than under the baseline and more than $1 \frac{1}{2}$ percentage points higher than under an expenditureoriented consolidation in 2011-15, leading to higher real interest rates. ${ }^{4}$ Weaker growth prospects and higher interest rates reverberate into slightly lower consumption and investment, which is partly offset by an improved trade balance by about $0.2-$ 0.4 percentage points of GDP by 2015 relative to the baseline.

\footnotetext{
${ }^{4}$ The higher inflation would be particularly undesirable, given the large share of CPI- indexed loans, which constituted 19 percent of Icelandic banks' loan portfolios at end-April 2010.
} 
Figure 2. Fiscal Adjustment Mix and Aggregate Demand (Deviation from the baseline in percent of GDP)

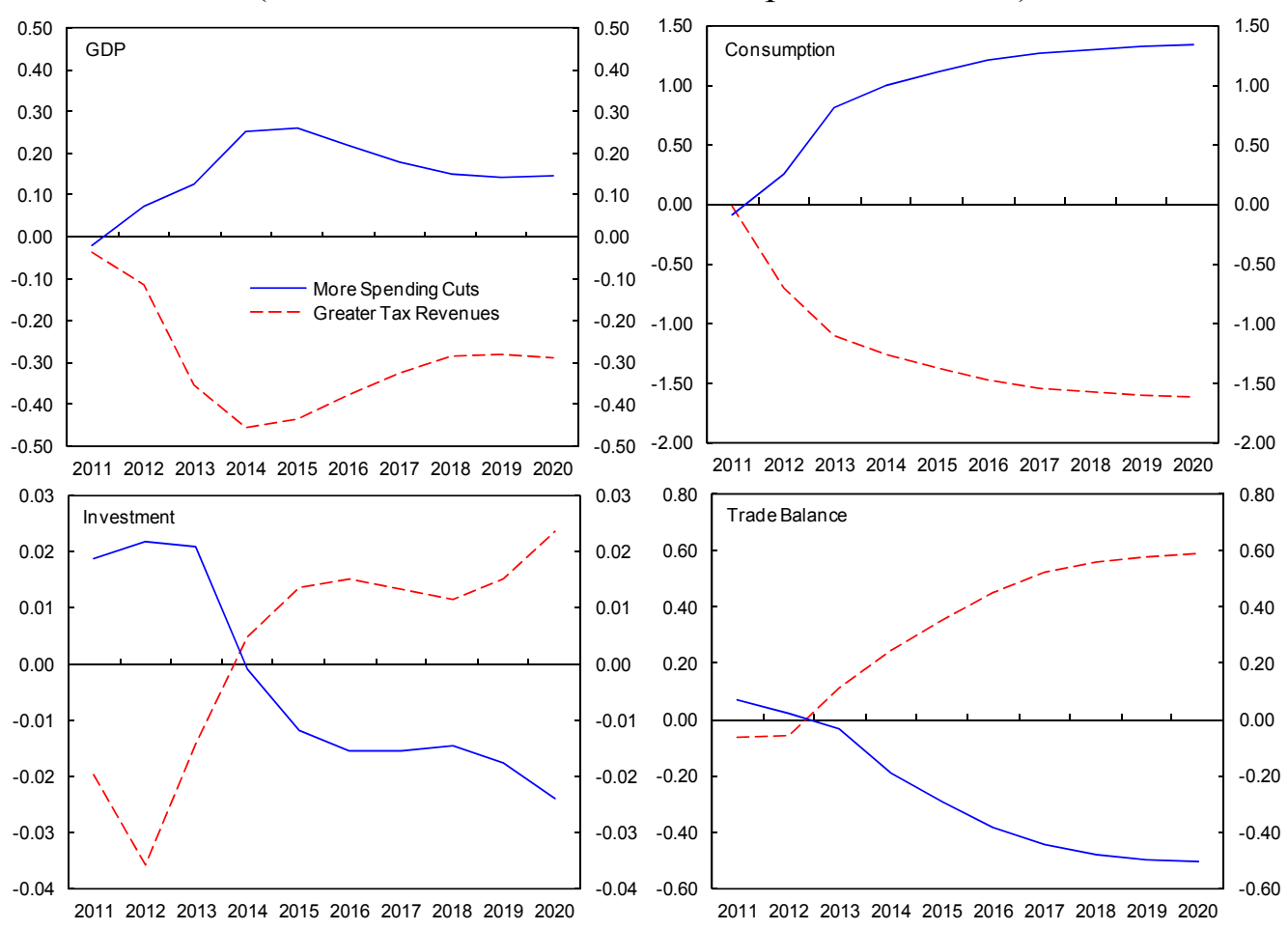

Source: IMF staff calculations.

Figure 3. Effect of the Fiscal Adjustment Mix on Growth and Inflation

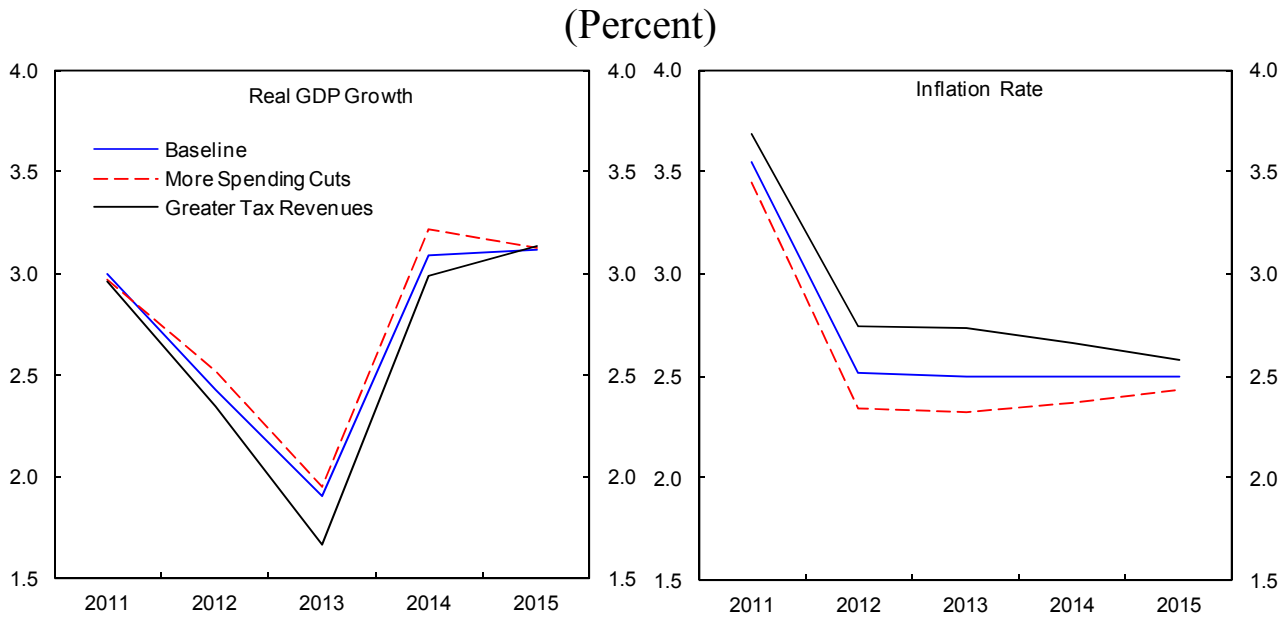

Source: IMF staff calculations.

Note: Real GDP growth and the inflation rate are calculated by adding the difference between each scenario and the baseline to the rates projected by IMF staff under the baseline. 


\section{Sensitivity to the fiscal adjustment mix}

15. Does the precise adjustment mix matter? For the case of a more expenditureoriented adjustment, possible scenarios include: (i) a greater reduction in general transfers; and (ii) a greater reduction in public consumption than in the baseline, where transfers and public consumption are reduced by the same amount. For the case of a more revenueoriented adjustment, possible scenarios include: (i) increases in the VAT or other consumption taxes in 2011-13; (ii) increases in capital and/or the corporate income tax rate in 2011, and VAT or other consumption taxes in 2012-13; (iii) increases in PIT only in 2011-13; and (iv) increases in capital and/or the corporate income tax rate in 2011 and PIT in $2012-13$.

\section{Model simulations suggest that for expenditure-oriented adjustments a greater} emphasis on transfer cuts modestly boosts output. If 75 percent of the expenditure measures involve transfer cuts, cumulative GDP growth is more than $3 / 4$ percentage points higher than under the baseline by 2014, tripling the impact of scenario 1 , and 1 percentage point higher than under a consolidation with a greater cut of consumption spending. The intuition is that government investment and consumption impact aggregate demand directly, while reduction in transfers operate mainly through their effects on personal disposable incomes, with is widely accepted in the literature to have smaller multipliers. (Figure 4). The overall inflation rate and the debt reduction path remain similar under all expenditureoriented scenarios, although the better growth under a consolidation with greater transfer cuts reduces the debt ratio by an additional percentage point to a consolidation with greater cut in government consumption (Figure 5). 
Figure 4. Aggregate Demand under Expenditure-Oriented Fiscal Adjustment Scenarios (Deviation from the baseline in percent of GDP)
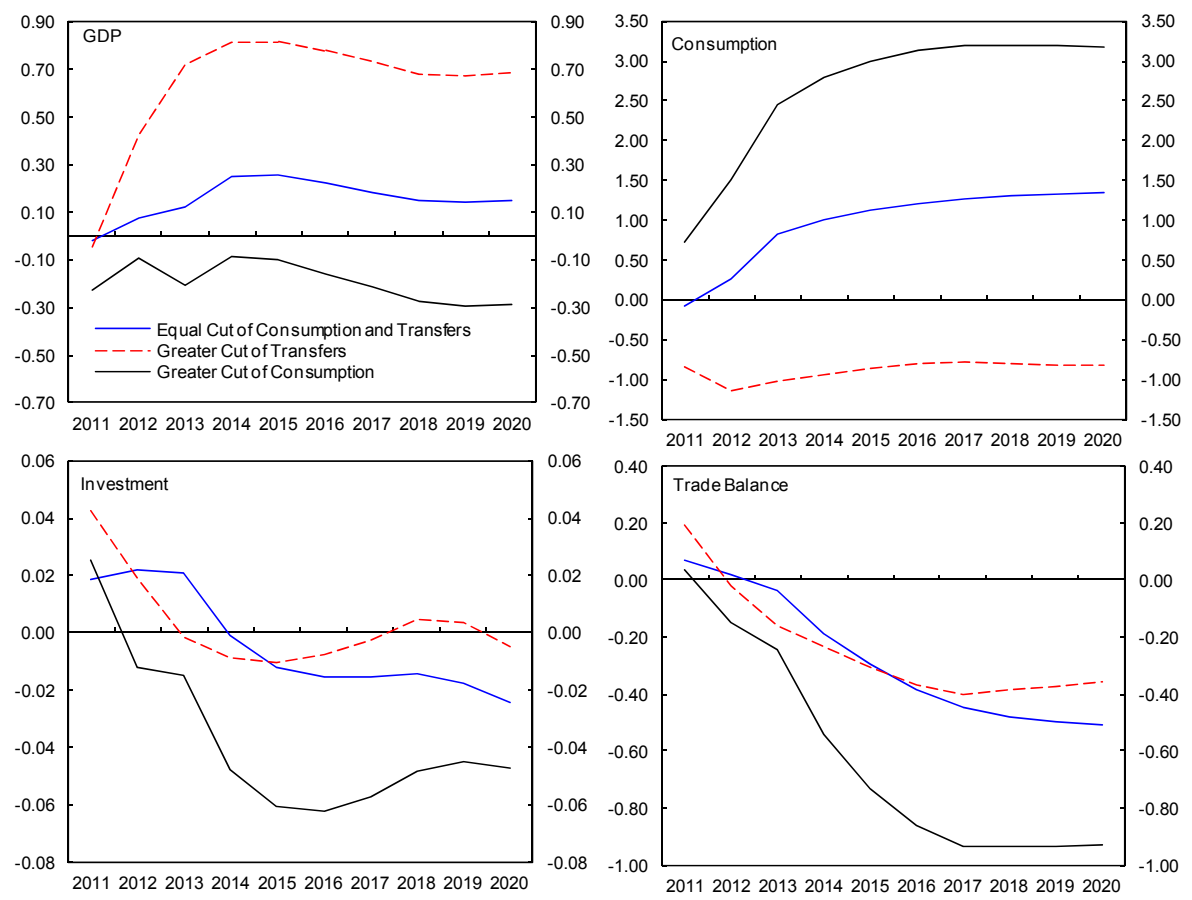

Source: IMF staff calculations.

Figure 5. Growth and Inflation under Expenditure-Oriented Fiscal Adjustment Scenarios (Percent)

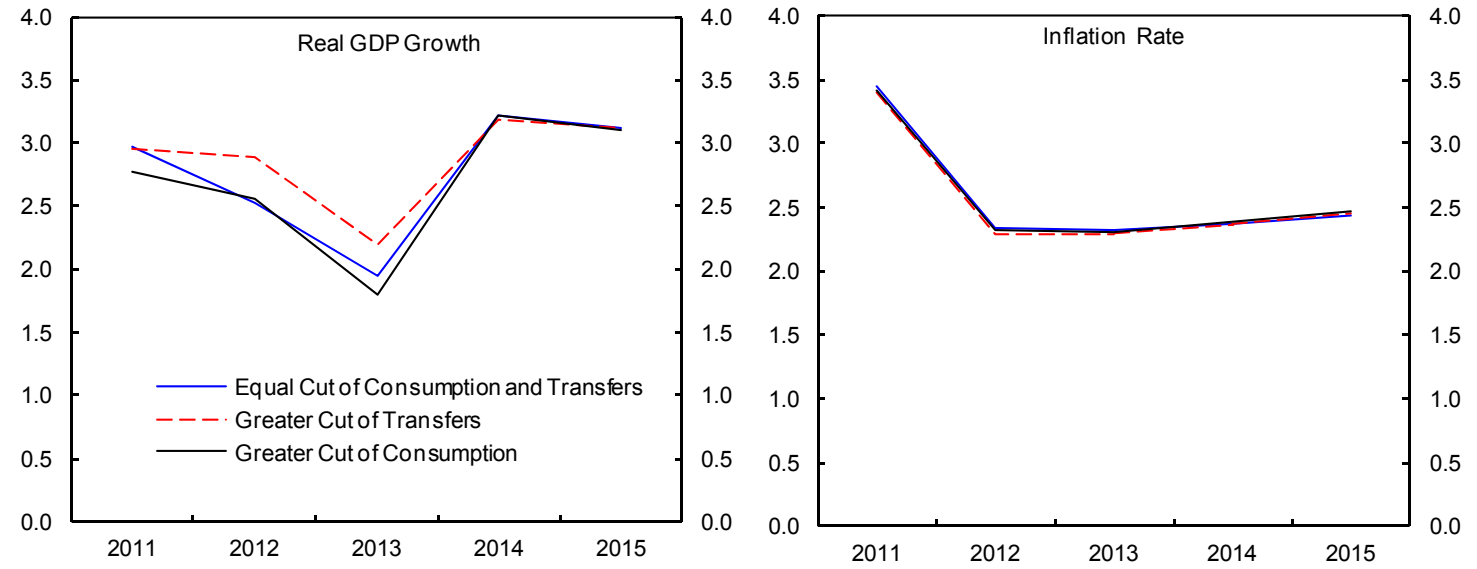

Source: IMF staff calculations.

17. Revenue-oriented scenarios keep GDP subdued, with some nuances. All scenarios which more heavily tax consumption reduce consumption by at least 0.8 percent of GDP by 2015 and tend to discourage investment (Figure 6). Under consolidation using only consumption taxes instead of income taxes, this effect is amplified by a higher inflation rate (11/4 percentage points in 2011-15) and the associated higher real interest rate due to the 
response of monetary policy (Figure 7). While consumption taxes allow the trade balance to improve, it is not sufficient to offset the decline in domestic demand: by 2014 consolidations relying on consumption taxes generate lower cumulative GDP growth than alternative revenue-based scenarios. Nonetheless, a fiscal adjustment plan that raises consumption tax revenues generates fewer distortions and redirects the economy toward export-led growth, and after 2015 cumulative GDP is higher than under consolidations relying on taxes on factor inputs. The debt ratio follows a similar path under all revenue-oriented scenarios, although an adjustment that relies exclusively on consumption tax revenues leads to a slightly higher debt ratio (by $3 / 4$ percent of GDP) in 2015 .

Figure 6. Aggregate Demand under Revenue-Oriented Fiscal Adjustment Scenarios (Deviation from the baseline in percent of GDP)
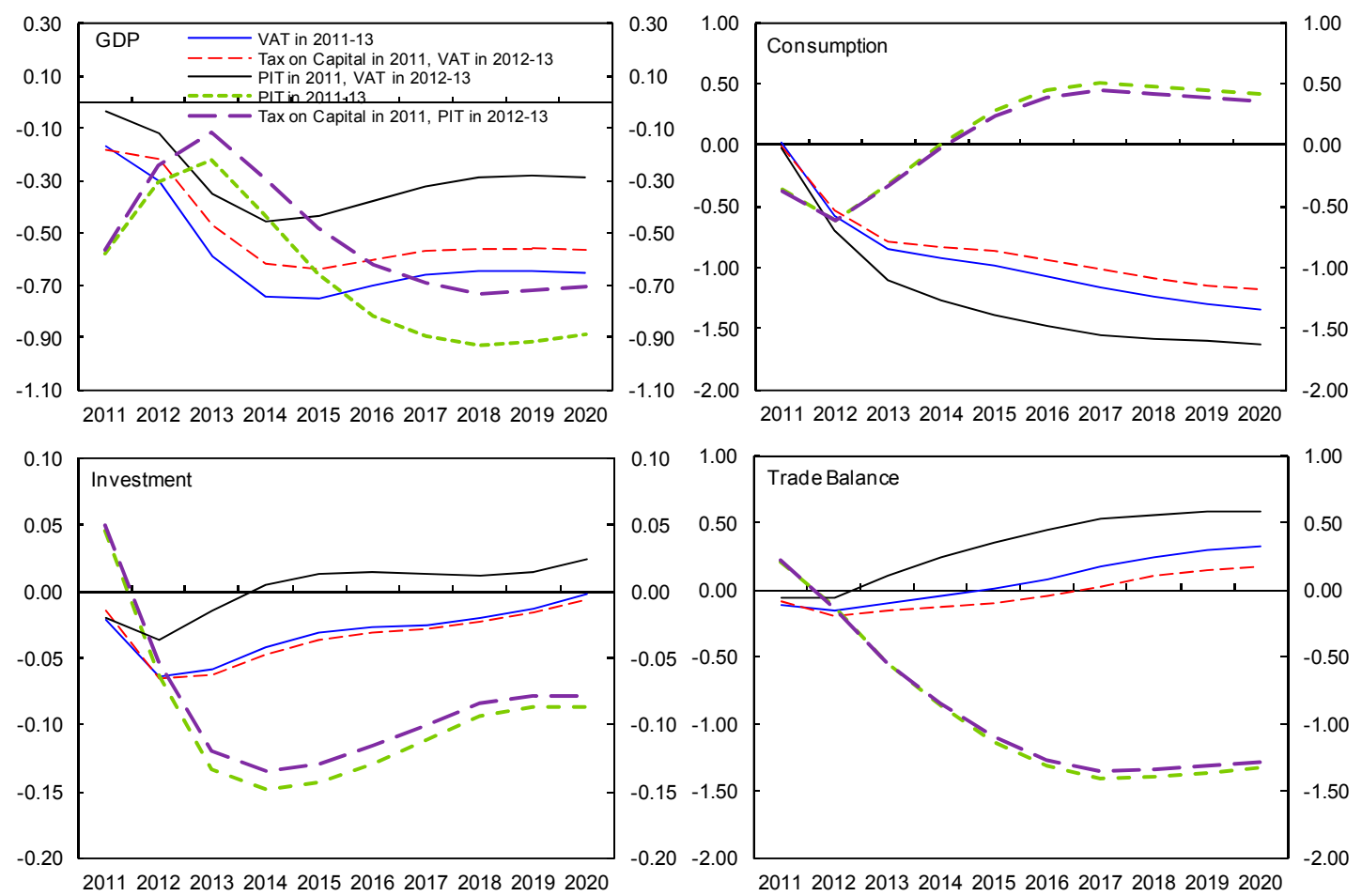

Source: IMF staff calculations. 
Figure 7. Growth and Inflation under Revenue-Oriented Fiscal Adjustment Scenarios (Percent)
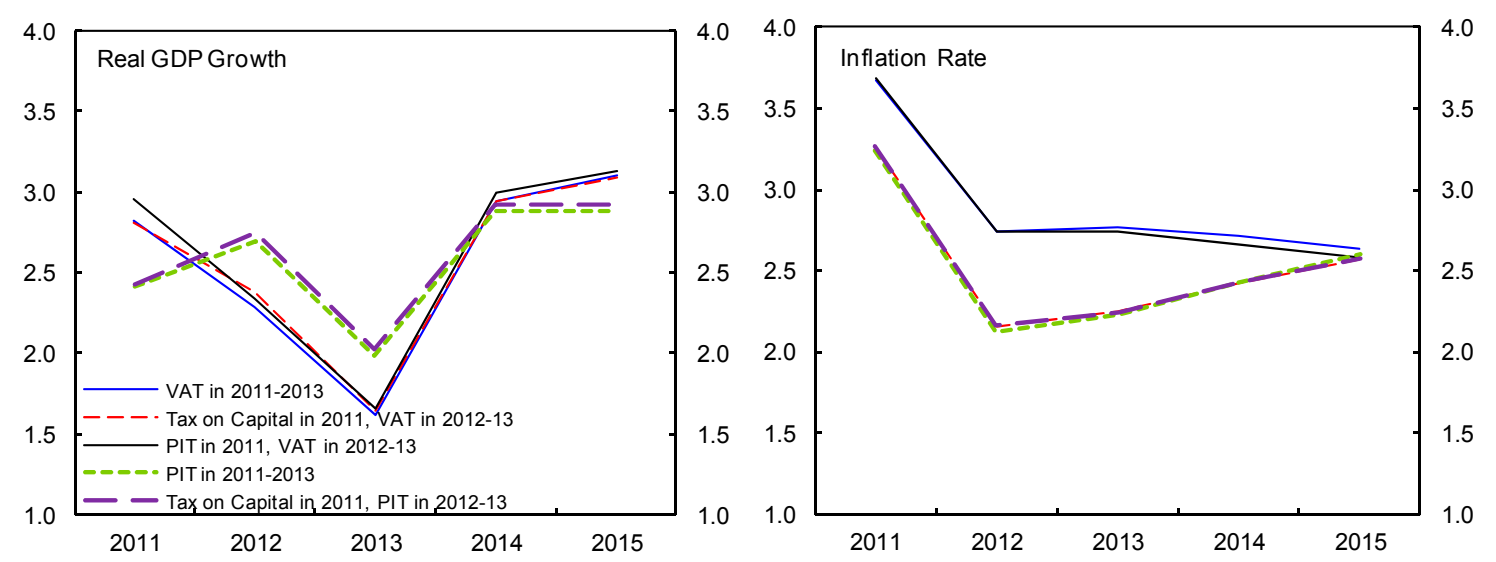

Source: IMF staff calculations.

\section{The Fiscal adjustment pace}

18. Model simulations suggest that small variations in the total amount of fiscal adjustment have no major impact. An adjustment in the primary balance that is about $1 / 2$ percentage point lower than in the baseline would be less restraining on consumption despite inducing a trade balance deterioration (Figure 8), and allows GDP to temporarily stay slightly above the baseline (Figure 9$){ }^{5}$

19. However, the pace of fiscal adjustment is of more importance. A delayed consolidation - assuming a primary balance 2 percentage points lower in 2011 offset by later surpluses - worsens borrowing conditions for the private sector by keeping pressure on the inflation rate and putting growing pressure on interest rates. It also leads to real appreciation in 2011-15 and deterioration of the trade balance. Private investment and aggregate demand are relatively subdued throughout the coming decade under delayed consolidation, and cumulative GDP growth is about 1 percent lower by 2014.

\footnotetext{
${ }^{5}$ A smaller consolidation may also trigger a negative confidence effect, particularly if it involves a deviation from the previously announced path. A possibly non-linear effect of such a scenario on risk premium is difficult to model.
} 
Figure 8. Fiscal Adjustment Pace and Aggregate Demand (Deviation from the baseline in percent of GDP)
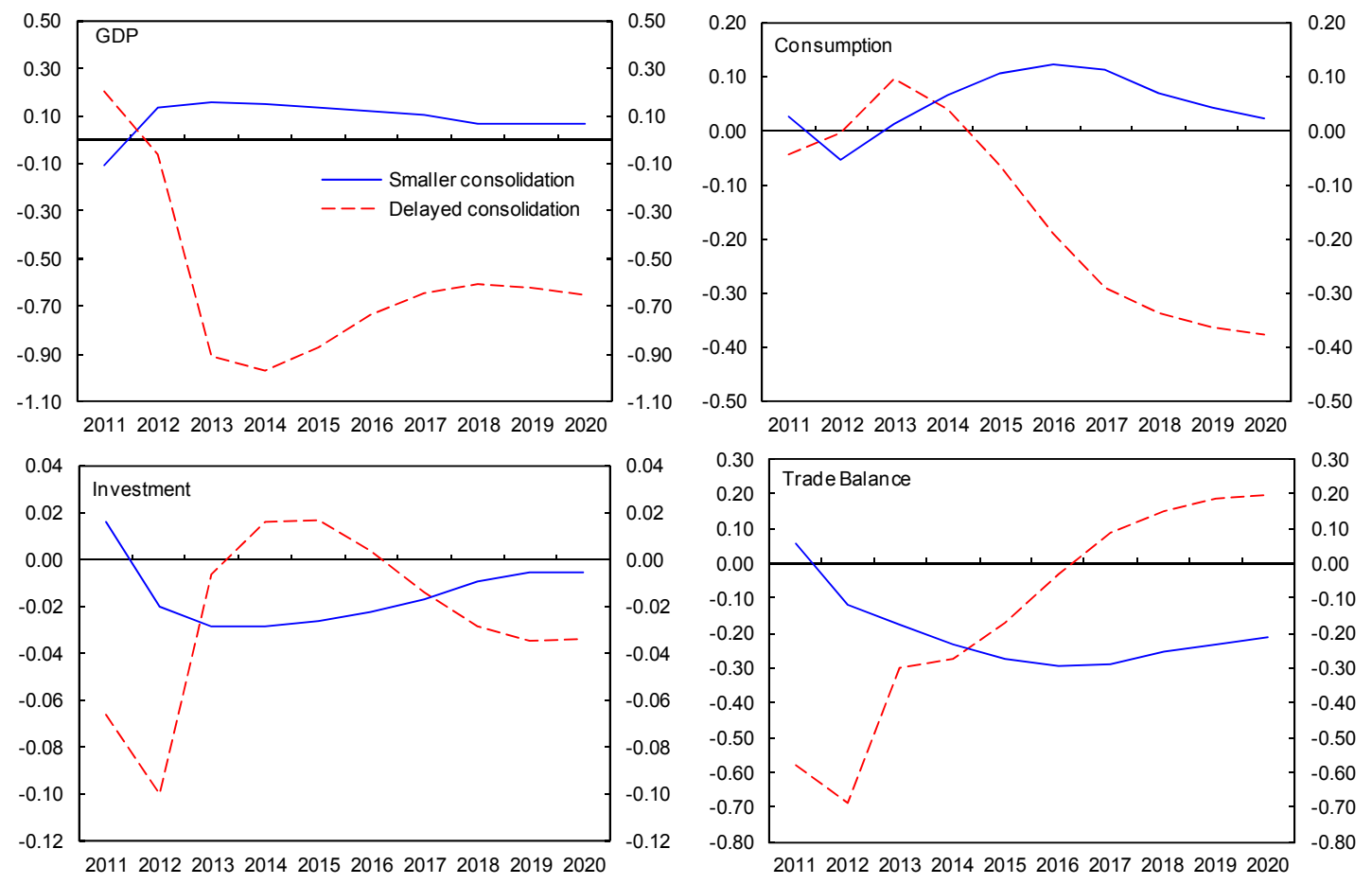

Source: IMF staff calculations.

Figure 9. Fiscal Adjustment Pace and Growth and Inflation (Percent)
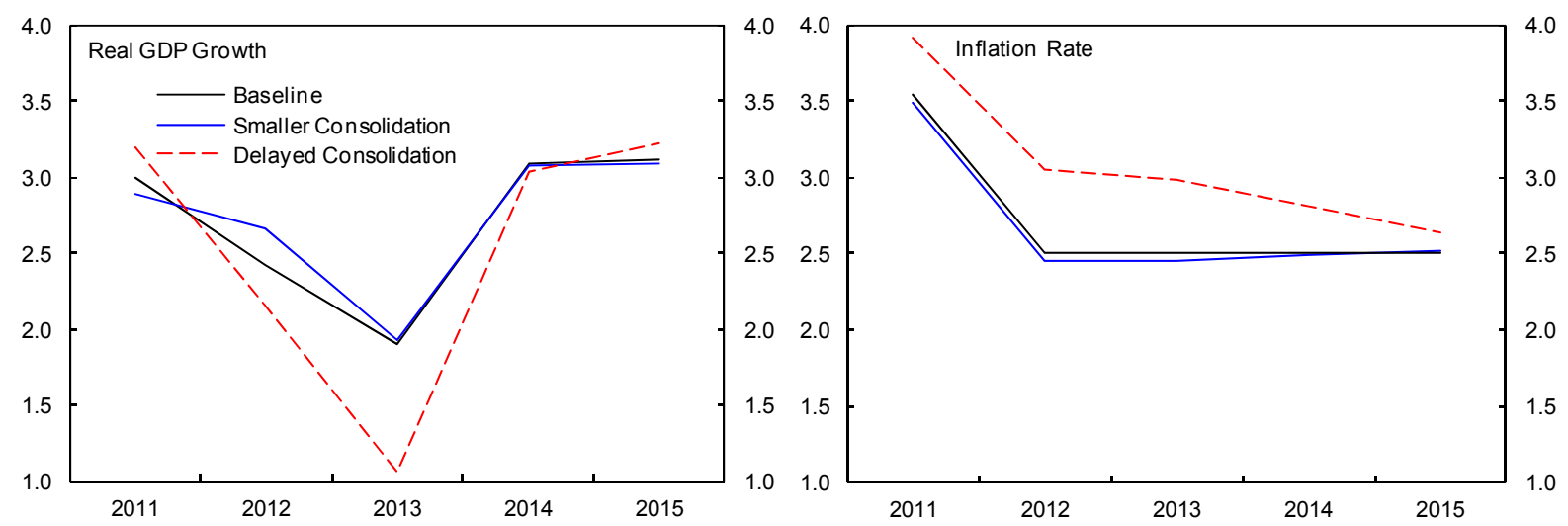

Source: IMF staff calculations. 


\section{The simulations suggest that the pace of fiscal consolidation has an important} bearing on debt reduction. Public debt declines steadily and in 2020 is at or under 60 percent of GDP under all scenarios except delayed consolidation. Due to the more sluggish growth, a delayed consolidation leaves the public debt at a level almost 5 percent of GDP higher than the baseline (Figure 10). A $1 / 2$ percentage point of GDP smaller adjustment modestly elevates debt in the long-run (by $3 \frac{1 / 4}{4}$ percent of GDP), but

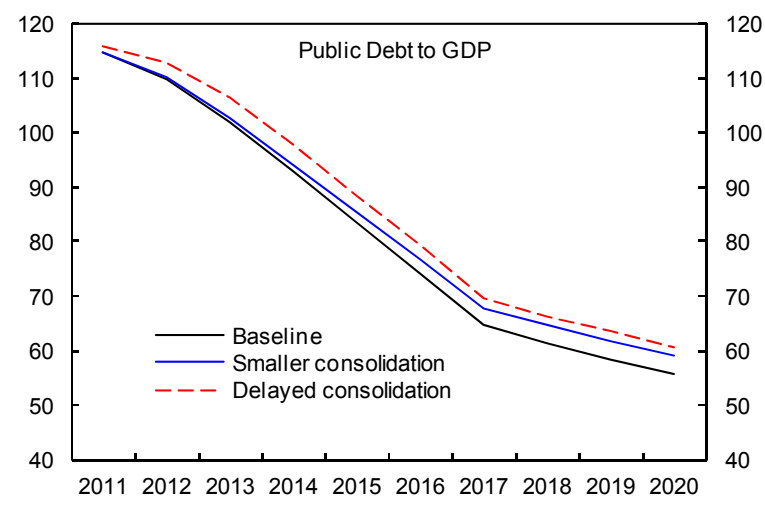
entails much lower interest costs, especially in 2011-15.

Figure 10. Fiscal Adjustment Pace and Aggregate Demand and Public Debt (Deviation from the baseline in percent of GDP)

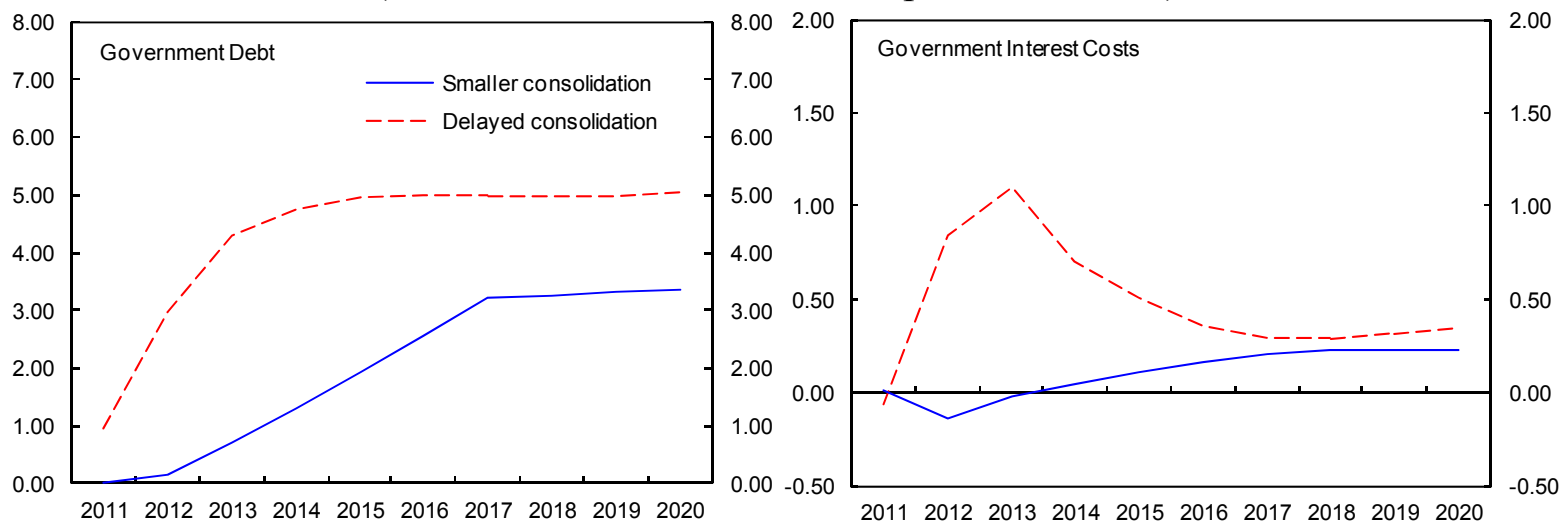

Source: IMF staff calculations.

\section{Sensitivity analysis and the fiscal adjustment pace}

\section{How robust are results on the pace of adjustment to underlying assumptions?}

Two scenarios are considered. First, a higher risk premium, perhaps due to premature or missequenced capital control liberalization (a model-based estimation ${ }^{6}$ suggests that under normal market conditions and given Iceland's public debt level, Iceland's long-term government bond yields would be about 200 basis points higher than observed). Second, materializing contingent liabilities (commercial bank losses may call for a new round of bank

\footnotetext{
${ }^{6}$ IMF staff calculations, based on a fixed effects panel data estimation, which covers 17 countries and the period from 1998-2008, without accounting for capital controls. According to this estimation Iceland's projected 10-year government bond yield would average 9.8 percent of GDP compared to an IFS reported average of 7.6 percent.
} 
recapitalization, amounting to as much as 10 percent of GDP, and separately litigation risks remain) would increase public debt.

\section{Model simulations suggest that results are sensitive to the behavior of the risk}

premium on Iceland's debt. A 200-basis point increase in the foreign currency premium in 2011 slows down growth and slows the reduction of public debt (Table 3 and Figure 11). The initial real effective exchange rate depreciation - which could give a cumulative boost to growth by about $3 / 4$ percentage points in 2011-15wears off in the long-run, while the inflation rate remains elevated for most of the decade. The rise in the foreign currency risk premium burdens the government with additional interest payments of more than $1 \frac{1}{2}$ percent of GDP by 2013, which in combination with the sharply declining GDP

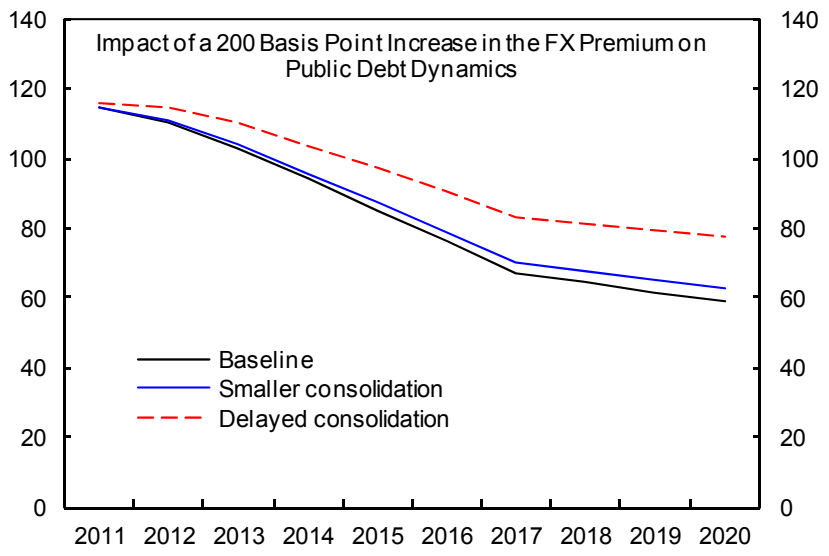
growth, levels off the long-term public debt path. In sum, an increase in the foreign currency premium would keep the 2020 public debt level more than 15 percent of GDP higher than under the main scenarios if the fiscal consolidation is delayed. This points to a need to carefully coordinate the fiscal adjustment path with the capital control liberalization path.

Table 3. Real Growth and Public Debt under FX Premium Shock

\begin{tabular}{|c|c|c|c|c|c|c|c|c|c|c|c|c|}
\hline \multicolumn{7}{|c|}{ Real GDP Growth } & \multicolumn{6}{|c|}{ Public Debt in Percent of GDP } \\
\hline \multirow[b]{2}{*}{ Year } & \multicolumn{3}{|c|}{ Main Scenarios } & \multicolumn{3}{|c|}{$\begin{array}{l}200 \text { Basis Point Increase } \\
\text { in the FX Risk Premium }\end{array}$} & \multicolumn{3}{|c|}{ Main Scenarios } & \multicolumn{3}{|c|}{$\begin{array}{l}200 \text { Basis Point Increase } \\
\text { in the FX Risk Premium }\end{array}$} \\
\hline & Baseline & Smaller & Delayed & Baseline & Smaller & Delayed & Baseline & Smaller & Delayed & Baseline & Smaller & Delayed \\
\hline 2011 & 3.0 & 2.9 & 3.2 & 2.7 & 2.6 & 3.2 & 115 & 115 & 116 & 115 & 115 & 116 \\
\hline 2012 & 2.4 & 2.7 & 2.2 & 3.1 & 3.4 & 2.7 & 110 & 110 & 113 & 111 & 111 & 115 \\
\hline 2013 & 1.9 & 1.9 & 1.1 & 2.3 & 2.3 & 1.4 & 102 & 103 & 106 & 103 & 104 & 110 \\
\hline 2014 & 3.1 & 3.1 & 3.0 & 3.2 & 3.2 & 2.9 & 93 & 94 & 98 & 94 & 96 & 104 \\
\hline 2015 & 3.1 & 3.1 & 3.2 & 2.9 & 2.9 & 3.0 & 84 & 86 & 89 & 85 & 87 & 97 \\
\hline 2016 & & & & & & & 74 & 77 & 79 & 76 & 79 & 90 \\
\hline 2017 & & & & & & & 65 & 68 & 70 & 67 & 70 & 83 \\
\hline 2018 & & & & & & & 61 & 65 & 66 & 64 & 68 & 81 \\
\hline 2019 & & & & & & & 59 & 62 & 64 & 62 & 65 & 79 \\
\hline 2020 & & & & & & & 56 & 59 & 61 & 59 & 63 & 77 \\
\hline
\end{tabular}

Source: IMF staff calculations. 
Figure 11. Impact of a 200 Basis Point Increase in the FX Risk Premium in 2011

(Deviation from Main Scenarios)
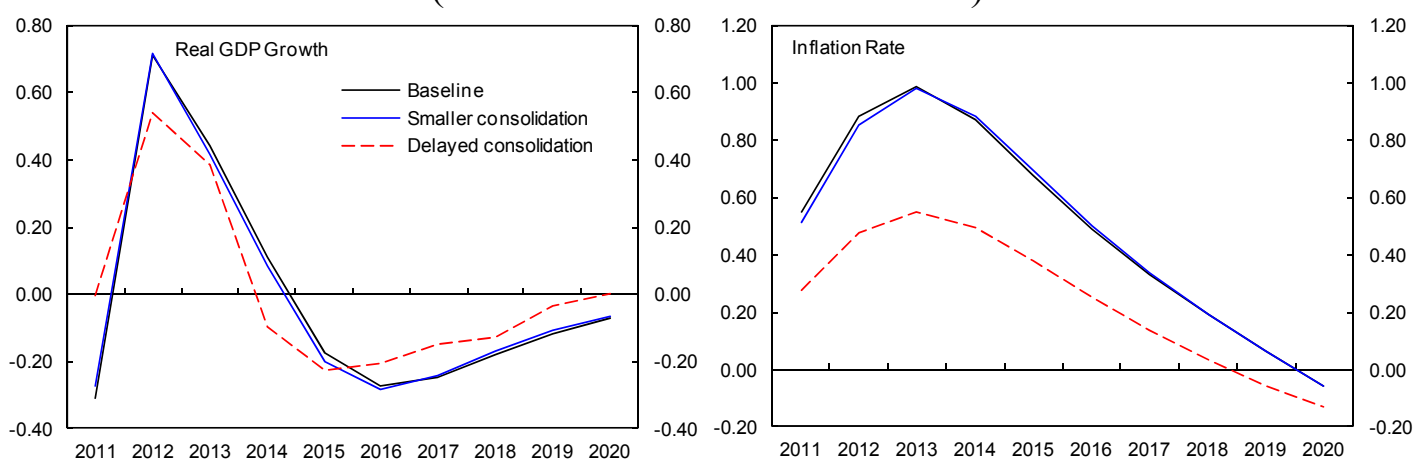

Source: IMF staff calculations.

\section{Results are also sensitive to}

public debt shocks. A 10 percent of

GDP shock to public debt increases the real interest rate and amplifies the effect of the private sector's net worth reduction in 2011, subsequently reducing investment. The shock also triggers further fiscal consolidation through reduction in household transfers, amplifying the negative GDP growth

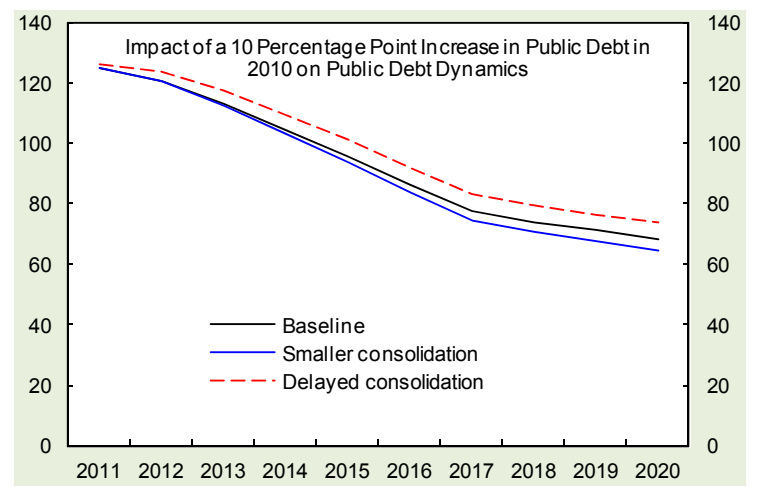
effect on the debt path.

24. The simulations suggest that a debt shock will delay achieving the authorities' objective of maintaining debt to GDP ratio of 60 percent. This is particularly the case for delayed consolidation, and the total impact on public debt 15 percent of GDP higher than if contingent liabilities were not assumed by the government. In sum, given a targeted path of debt reduction, variations in the fiscal adjustment path should only be considered once there is greater clarity about contingent fiscal liabilities.

\section{E. Conclusions}

\section{GIMF simulations underscore that the depth, composition and timing of the} fiscal adjustment have macroeconomic consequences. Domestic demand and growth would be modestly stronger under an expenditure-oriented adjustment than under a revenueoriented one. The small differences resulting from fiscal adjustment options with different compositions show that the authorities' aspiration to reduce the ratio of long-term debt to GDP to 60 percent can be achieved with any policy mix. However, attention must be paid to the pace of consolidation: delay could stall debt reduction at above 75 percent of GDP. Finally, the pace of adjustment provides protection against debt shocks and an increase in the foreign currency risk premium, opening up greater room for other policies (e.g. capital control liberalization). 


\section{REFERENCES}

Allard, Céline and Sònia Muñoz, 2008, "Challenges to Monetary Policy in the Czech Republic_-An Integrated Monetary and Fiscal Analysis", IMF Working Paper $\underline{08 / 72}$.

Allard, Céline, Nada Choueiri, Susan Schadler, and Rachel Van Elkan, 2008, "Macroeconomic Effects of EU Transfers in New Member States", IMF Working Paper 08/223.

Annett, Anthony, 2007, “Toward a Robust Fiscal Framework for Iceland: Motivation and Practical Suggestions," IMF Working Paper 07/235.

Clinton, Kevin, Michael Kumhof, Douglas Laxton, and Susanna Mursula, 2010, Budget Consolidation: Short-Term Pain and Long-Term Gain.

Dmitriy Rozhkov, and Werner Schule, 2009, "Short-Term Benefits and Medium-Term Costs of Fiscal Stimulus," New Zealand: Selected Issues, IMF Country Report $\underline{09 / 146 .}$.

Escolano, Julio, Thornton Matheson, Christopher Heady, and Geerten Michielse, 2010, "Improving the Equity and Revenue Productivity of the Icelandic Tax System”, IMF Country Report No. 10/213.

Freedman, Charles, Michael Kumhof, Douglas Laxton, Dirk Muir, and Susanna Mursula, 2009, "Fiscal Stimulus to the Rescue? Short-Run Benefits and Potential Long-Run Costs of Fiscal Deficits", IMF Working Paper 09/255.

Hughes, Richard, 2010, Applying Fiscal Rules to the Public Sector: Lessons from International Experience, [Presentation]

Freedman, Charles, Michael Kumhof, Douglas Laxton, and Jaewoo Lee, 2009, The Case for Global Fiscal Stimulus, IMF Staff position Note 09/03.

Michael Kumhof, Günter Coenen, Dirk Muir, Charles Freedman, Susanna Mursula, Christopher J. Erceg, Davide Furceri, Rene Lalonde, Jesper Lindé, Annabelle Mourougane, John Roberts, Werner Röger, Stephen Snudden, Mathias Trabandt, Jan In't Veld, 2010. "Effects of Fiscal Stimulus in Structural Models," IMF Working Papers 10/73.

Kumhof, Michael, and Douglas Laxton, 2009, The Global Integrated Monetary and Fiscal Model-Technical Appendix, http://www.douglaslaxton.org/sitebuildercontent/sitebuilderfiles/gimftechnical appendix.pdf .

Kumhof, Michael, Douglas Laxton, Dirk Muir, and Susanna Mursula, 2010, Global Integrated Monetary and Fiscal Model-Theoretical Structure, IMF Working Paper 10/34. 
Leigh, Daniel, 2008, “Achieving a Soft Lending: The Role of Fiscal Policy,” IMF Working Paper 08/69.

Ministry of Finance of Iceland, 2009, Measures to Achieve a Balance in Fiscal Finances 2009-2013-Stability, Welfare, and Work, Report by the Minister of Finance to the 137the Session of the Althingi.

OECD, 2009, Economic Surveys: Iceland, Volume 2009(16).

Ostry, Jonathan, Atish Ghosh, Jun Kim, and Mahvash Qureshi, 2010, "Fiscal Space”, IMF Staff Position Note 10/11.

Pétursson, Pórarinn G., 2000, "The Representative Household's Demand for Money in a Cointegrated VAR Model," Econometrics Journal, 3, 162-176. 
APPENDIX I. MODEL ASSUMPTIONS

\begin{tabular}{|c|c|c|}
\hline Variable & Iceland & Rest of the World \\
\hline GDP (percent share of world nominal GDP) & 0.12 & 99.88 \\
\hline \multicolumn{3}{|l|}{ National Expenditure Accounts(percent share of GDP) } \\
\hline Consumption & 53.21 & 64.60 \\
\hline Liquidity-constrained agents & 25.47 & 7.44 \\
\hline Overlapping generation agents & 34.44 & 53.16 \\
\hline Investment & 13.00 & 15.90 \\
\hline Government spending & 27.00 & 23.50 \\
\hline On consumption & 24.50 & 20.50 \\
\hline On investment & 2.50 & 3.00 \\
\hline Exports & 44.21 & 0.05 \\
\hline Of final goods & 26.87 & 0.03 \\
\hline Of intermediate goods & 17.34 & 0.02 \\
\hline Imports & -44.13 & -0.42 \\
\hline Of final goods & -29.86 & -0.03 \\
\hline consumption goods & -23.55 & -0.03 \\
\hline investment goods & -6.31 & 0.00 \\
\hline Of intermediate goods & -14.27 & -0.02 \\
\hline \multicolumn{3}{|l|}{ National income accounts (percent share of GDP) } \\
\hline Wages and dividends & 59.54 & 59.70 \\
\hline Capital income & 23.52 & 28.15 \\
\hline Taxes on wages & 16.94 & 12.15 \\
\hline Taxes on capital & 4.62 & 4.05 \\
\hline Government revenue & 30.50 & 26.50 \\
\hline \multicolumn{3}{|l|}{ Assets and Debt } \\
\hline Government debt (percent share of GDP) & 118.00 & 60.00 \\
\hline government deficit & 6.80 & 3.18 \\
\hline primary balance & 1.39 & 0.01 \\
\hline interest payments & 8.19 & 3.19 \\
\hline \multicolumn{3}{|l|}{ Structural Parameters } \\
\hline Population growth, percent p.a. & 1.00 & 1.00 \\
\hline Intertemporal elasticity of substitution & 2.00 & 0.20 \\
\hline Probability of survival (20 year planning horizon) & 0.95 & 0.95 \\
\hline Income decline rate (20 year remaining working life) & 0.95 & 0.95 \\
\hline Share of liquidity-constrained agents & 0.50 & 0.15 \\
\hline \multicolumn{3}{|l|}{ Elasticities of substitution } \\
\hline Home/foreign final goods & 1.50 & 1.50 \\
\hline Home/foreign intermediate goods & 1.50 & 1.50 \\
\hline Tradable/nontradable & 0.80 & 0.80 \\
\hline \multicolumn{3}{|l|}{ Commodities } \\
\hline Capital/Labor & 0.99 & 0.99 \\
\hline Depreciation rate of private capital, percent p.a. & 9.00 & 9.00 \\
\hline Depreciation rate of public capital, percent p.a. & 4.00 & 4.00 \\
\hline
\end{tabular}


APPendix 2. Main Fiscal AdJUSTMent Scenarios

\begin{tabular}{|c|c|c|c|c|c|c|c|c|c|c|c|c|c|c|c|c|c|c|c|c|c|}
\hline & \multirow[b]{3}{*}{ 웅 } & \multicolumn{4}{|c|}{ Baseline } & \multicolumn{4}{|c|}{ Scenario 1} & \multicolumn{4}{|c|}{ Scenario 2} & \multirow{2}{*}{\multicolumn{4}{|c|}{$\begin{array}{c}\text { Scenario } 3 \\
\text { Smaller Consolidation } \\
\text { Balanced Measures } \\
\text { (45/55 Rule })\end{array}$}} & \multirow{2}{*}{\multicolumn{4}{|c|}{$\begin{array}{c}\text { Scenario } 4 \\
\text { Delayed Consolidation } \\
\text { Balanced Measures } \\
\text { (45/55 Rule })\end{array}$}} \\
\hline & & \multicolumn{4}{|c|}{$\begin{array}{l}\text { Balanced Measures } \\
\quad(45 / 55 \text { Rule })\end{array}$} & \multicolumn{4}{|c|}{ More Spending Cuts } & \multicolumn{4}{|c|}{ Greater Tax Revenues } & & & & & & & & \\
\hline & & $\frac{\pi}{\grave{n}}$ & $\stackrel{N}{\sim}$ & $\stackrel{m}{\grave{N}}$ & $\xi_{0}^{\dot{3}}$ & 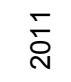 & $\stackrel{N}{\mathfrak{N}}$ & $\stackrel{m}{\grave{n}}$ & $\xi_{\mathcal{S}}^{\dot{3}}$ & $\overline{\check{c}}$ & $\stackrel{\sim}{\mathfrak{N}}$ & $\stackrel{m}{\stackrel{m}{N}}$ & $\sum_{\mathcal{S}}^{\dot{3}}$ & $\stackrel{i}{\bar{\sigma}}$ & $\stackrel{N}{\grave{N}}$ & $\stackrel{m}{\grave{N}}$ & $\xi_{0}^{\dot{\xi}}$ & 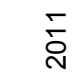 & $\stackrel{\sim}{\grave{N}}$ & $\stackrel{m}{\grave{n}}$ & $\xi_{0}^{\xi}$ \\
\hline Primary Balance & -2.7 & 0.6 & 3.8 & 6.0 & & 0.6 & 3.8 & 6.0 & & 0.6 & 3.8 & 6.0 & & 0.8 & 3.3 & 5.4 & & -1.2 & 2.0 & 6.0 & \\
\hline $\begin{array}{l}\text { Change in the primary } \\
\text { balance }\end{array}$ & & 3.3 & 3.2 & 2.2 & 8.7 & 3.3 & 3.2 & 2.2 & 8.7 & 3.3 & 3.2 & 2.2 & 8.7 & 3.5 & 2.5 & 2.1 & 8.1 & 1.5 & 3.2 & 4.0 & 8.7 \\
\hline $\begin{array}{l}\text { Revenue Increasing } \\
\text { Measures }\end{array}$ & & 0.1 & 1.0 & 1.0 & 2.2 & 0.1 & 0.4 & 0.3 & 0.7 & 0.4 & 2.3 & 1.5 & 4.2 & 0.1 & 0.8 & 1.0 & 1.9 & 0.0 & 1.0 & 1.9 & 3.0 \\
\hline $\begin{array}{l}\text { Increase in PIT } \\
\text { Revenues } \\
\text { Increase in VAT }\end{array}$ & & 0.1 & 0.0 & 0.0 & 0.1 & 0.1 & 0.0 & 0.0 & 0.1 & 0.4 & 0.0 & 0.0 & 0.4 & 0.1 & 0.0 & 0.0 & 0.1 & 0.0 & 0.0 & 0.0 & 0.0 \\
\hline Revenues & & 0.0 & 1.0 & 1.0 & 2.1 & 0.0 & 0.4 & 0.3 & 0.7 & 0.0 & 2.3 & 1.5 & 3.8 & 0.0 & 0.8 & 1.0 & 1.8 & 0.0 & 1.0 & 1.9 & 3.0 \\
\hline Expenditure Reducing & & & & & & & & & & & & & & & & & & & & & \\
\hline $\begin{array}{l}\text { Measures } \\
\quad \text { Reduction in Consumption }\end{array}$ & & 3.2 & 2.2 & 1.2 & 6.5 & 3.2 & 2.8 & 1.9 & 8.0 & 2.9 & 0.9 & 0.7 & 4.5 & 3.4 & 1.7 & 1.1 & 6.2 & 1.5 & 2.2 & 2.1 & 5.7 \\
\hline Spending & & 1.3 & 1.1 & 0.6 & 2.9 & 1.3 & 1.4 & 1.0 & 3.7 & 1.2 & 0.5 & 0.3 & 1.9 & 1.4 & 0.8 & 0.5 & 2.7 & 0.6 & 1.1 & 1.0 & 2.7 \\
\hline Reduction in Transfers & & 1.3 & 1.1 & 0.6 & 2.9 & 1.3 & 1.4 & 1.0 & 3.7 & 1.2 & 0.5 & 0.3 & 1.9 & 1.4 & 0.8 & 0.5 & 2.7 & 0.6 & 1.1 & 1.0 & 2.7 \\
\hline $\begin{array}{l}\text { Reduction in Capital } \\
\text { Spending }\end{array}$ & & 0.6 & 0.0 & 0.0 & 0.6 & 0.6 & 0.0 & 0.0 & 0.6 & 0.6 & 0.0 & 0.0 & 0.6 & 0.7 & 0.0 & 0.0 & 0.7 & 0.3 & 0.0 & 0.0 & 0.3 \\
\hline $\begin{array}{l}\text { Proportion of revenue } \\
\text { measures }\end{array}$ & & 3.1 & 32.8 & 47.7 & & 2.2 & 12.2 & 12.2 & & 12.8 & 71.8 & 68.7 & & 3.1 & 32.8 & 47.7 & & 3.1 & 32.8 & 47.7 & \\
\hline
\end{tabular}

